\title{
WORKING
}

paper

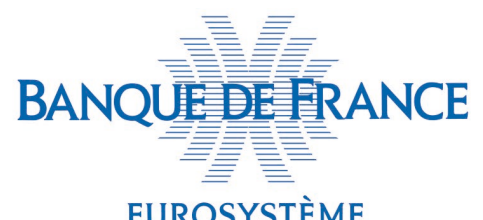

EUROSYSTÈME

\section{Price effect of mutual fund flows on the corporate bond market. The French case}

\author{
Virginie Coudert $^{1}$, Dilyara Salakhova ${ }^{2}$
}

\author{
May 2019, WP \#706
}

\begin{abstract}
We study how investors' withdrawals from mutual funds may affect the French corporate bond market. We use monthly data on flows to the French bond and mixed mutual funds as well as a database on their bond holdings at the bond-level from 2011 to 2017 provided by the Banque of France Statistics Department. Using a large sample of French corporate bonds held by funds, we run panel data regressions at the bond-level to explain their yields by macroeconomic variables, such as the sovereign 10-y rate, the short-term rate, the Vstoxx as well as bond-specific variables, such as the residual maturity, liquidity and the issuer's probability of default. We also account for the corporate securities purchasing programme (CSPP) implemented by the ECB since June 2016 by adding dummy variables on the eligible bonds. Then we add variables related to inflows/outflows to test for several hypotheses. First, our results show that flows to funds affect the yields of all corporate bonds across the board. Second, this effect is asymmetric since outflows have a greater impact on yields than inflows. Third, the greater the funds' market share in a specific bond the higher the impact on this bond is. These three results are robust to change in econometric specification. Further estimations suggest that withdrawals may raise liquidity premia and ownership by funds could amplify the response of bond yields to financial stress, although these two latter results are not significant in all econometric specifications.
\end{abstract}

Keywords: investment funds, bond holdings, bond yields, fund flows, financial stability.

JEL classification: G12; G23

\footnotetext{
${ }^{1}$ Banque de France, virginie.coudert@banque-france.fr

2 Banque de France, dilyara.salakhova@banque-france.fr

The authors thank Raphaëlle Bellando, Jean Boissinot, Régis Breton, Laurent Clerc, Olivier Cousseran, Hugues Dastarac, Stéphane Dees, Alain Duchateau, Julien Idier and Ivan Odonnat for their helpful comments on an earlier version of the paper. We also thank the participants to the Bank of France internal seminars for their comments and Jonathan Zribi (Bank of France) for useful discussions. We are also grateful to the Statistics Department of the Bank of France for providing the data base on the funds' holdings as well as Valérie Chouard and Delphine Terrade from the Financial Stability Department for their help in constructing the dataset. The views expressed in the paper are solely those of the author(s) and do not necessarily represent the views of the Eurosystem or the Banque de France.
} 


\section{NON-TECHNICAL SUMMARY}

Assets under management (AUM) by investment funds have surged for the last decade in most countries. They amounted to $€ 11$ trillion in the euro area in 2017, which is about the size of the annual GDP. French investment funds play an important role in the euro area financial landscape, as they now rank fourth behind Luxembourg, Germany and Ireland, holding $10 \%$ of the all euro area funds' assets (Ponsart and Salvio, 2018).

This significant development in asset management sector due to the low interest rate environment and more market-based finance orientation raises many questions regarding financial stability. A key vulnerability of bond funds involves possible liquidity mismatch between their assets and liabilities particularly in the presence of first-mover advantage. Indeed, when funds with less liquid assets face investors' fund outflows, they may exert an adverse impact on prices of assets they sell in order to meet investors' demand. In this paper, we analyze the effects on the French corporate bond market exerted by the French bond and mixed mutual funds that represent about a half of the French asset management sector ( $€ 638$ bn of AUM in 2017).

We use Bank of France monthly data on the total flows in and out of all French bond and mixed funds as well as on the amount of bonds held by these funds at the bond-level from July 2011 to December 2017. Among all the bonds held by these funds, we only retain those issued by French non-financial companies for two reasons. First, there is a substantial home bias that makes French issuers predominant in the funds' portfolio. Second, the lower liquidity of corporate bonds compared to that of sovereigns or financials incite us to think that their price may be more sensitive to funds' transactions.

The figure below shows the monthly net flows into French bond and mixed funds weighted by their total net assets from 2011 to 2017. The net flows turn out to be very volatile, often switching between net inflows and withdrawals. Net redemptions occur in about $40 \%$ of the time sample and reached their peak at the height of the European sovereign debt crisis in summer 2012.

\section{Monthly net flows into French bond and mixed funds, as \% of total net assets}

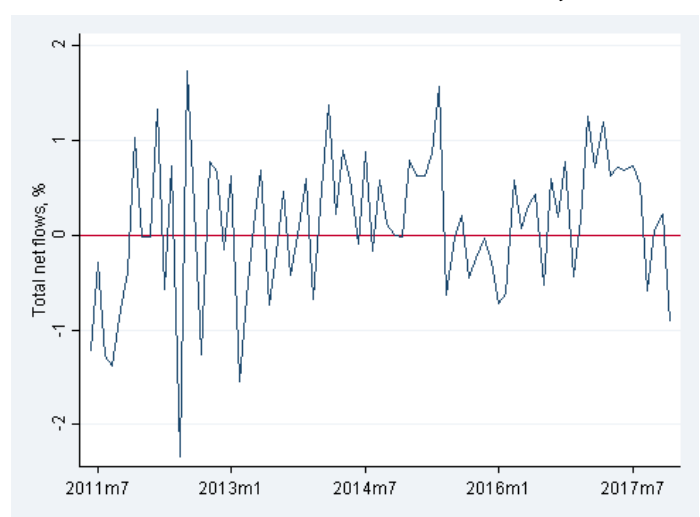

The aim of the paper is to identify the effect of these fund net flows on corporate bond yields. To do so, we estimate regressions at the bond-level that explain yields by macroeconomic variables, such as the sovereign 10-y rate, the short-term rate, the Vstoxx as well as bond-specific variables, such as the residual maturity, liquidity and the issuer's probability of default. We also account for the corporate securities purchasing programme (CSPP) implemented by the ECB since June 2016 by adding dummy variables on the eligible bonds. More specifically, we test for several hypotheses about the responses of bond yields to net flows of funds at a bond-level. First, we verify that flows in and out of mutual funds affect corporate bond yields. Second, we test for a concave relationship between fund flows and bond prices that may stem from the low liquid nature of corporate bonds. Namely we want to determine if outflows affect bond yields to a greater extent than inflows. Third, we test if the impact on yields due to the funds' flows is stronger for the bonds that funds hold a larger share of. The estimations strongly confirm these three hypotheses and the results are found robust to changes of econometric specification. 
We also test for two additional hypotheses. First, we find some evidence that the yields of less liquid bonds are more sensitive to redemptions. Our data show that when facing redemptions, funds tend to sell all bonds regardless of their liquidity whereas previous studies (Chernenko and Sunderam (2016), Jiang et al. (2018)) showed that outflows touch all asset classes but particularly the most liquid ones (cash-like securities, government bonds, etc.). However, they did not did not study price effects across asset classes. Second, our findings on the adverse effect of greater ownership concentration on the bond yields show some evidence of an amplifying effect however the result is very sensitive to econometric specifications.

Two conclusions are particularly important for financial stability and tend to reinforce some results in the previous literature. First, bond funds exert a significant impact on the bond prices (or yields), especially when facing investors' redemptions. These results are consistent with the few existing papers for the US (Chernenko and Sunderam, 2016; Choi and Shin, 2016), though studies on the subject are rather scarce. Second, we find that the larger the funds' holdings in a given bond, the larger the price effect on this bond. This finding may be related to similar results for institutional trading in equity markets (see, e.g., Greenwood and Thesmar, 2011). This draws particular attention to the concentration of asset holdings by one institution or one type of institutions.

\section{L'effet des fonds mutuels sur les obligations d'entreprises. Le cas français}

\section{RÉSUMÉ}

Nous étudions comment les retraits des fonds communs de placement (OPC) par les investisseurs peuvent affecter le marché français des obligations d'entreprises. Nous utilisons des données mensuelles sur les flux des OPC obligataires et mixtes français ainsi qu'une base de données sur leurs avoirs détaillée au niveau de chaque obligation de 2011 à 2017. Après avoir sélectionné les données d'obligations d'entreprises françaises détenues par les fonds, nous procédons à des régressions de données de panel afin d'expliquer leurs rendements à l'aide de variables macroéconomiques, telles que le taux souverain 10 ans, le taux à court terme, le Vstoxx ainsi que des variables spécifiques à chaque obligation, telles que la maturité résiduelle, la liquidité et la probabilité de défaut de l'émetteur. Nous prenons également en compte le programme d'achat de titres de sociétés (CSPP) mis en œuvre par la BCE depuis juin 2016 en ajoutant des variables muettes sur les obligations éligibles. Ensuite, nous ajoutons des variables liées aux entrées / sorties pour tester plusieurs hypothèses. Nos résultats montrent que, premièrement, les flux (versements ou retraits) sur les fonds affectent les rendements des obligations. Deuxièmement, cet effet est asymétrique car les retraits ont un impact plus important sur les rendements que les versements. Troisièmement, plus la part de marché des fonds dans une obligation spécifique est importante, plus l'impact sur cette obligation est important. Ces trois résultats sont robustes au changement de spécification économétrique.

Mots-clés : fonds d'investissement, fonds mutuels, obligations d'entreprises, flux dans les fonds, stabilité financière

Les Documents de travail reflètent les idées personnelles de leurs auteurs et n'expriment pas nécessairement la position de la Banque de France. Ils sont disponibles sur publications.banque-france.fr 


\section{Introduction}

Assets under management by investment funds have surged for the last decade in most countries. They amounted to $€ 11$ trillion in the euro area in 2017, which is about the size of the annual GDP. This tremendous development potentially related to the low interest rate environment raises many questions regarding financial stability. Fixed income mutual funds stand out in this debate for three reasons. First, they have attracted several times more inflows than all the other funds combined since the crisis (Feroli et al. (2014)). Second, they invest in rather illiquid assets such as corporate bonds. Third, unlike equity mutual funds, little research is available on bond funds due to the scarcity of the data. In this paper, we use detailed data on corporate bond holdings by French bond and mixed mutual funds in order to study how funds' flows affect bond yields.

A key vulnerability of bond funds involves possible liquidity mismatch between assets and liabilities in open-ended funds, i.e. the difference between the ease and speed with which investors may redeem their units and the ease and speed with which portfolio assets can be sold. This mismatch creates a risk of runs linked to the presence of a first-mover advantage in the redemption decision due to the fact that funds have to readjust their portfolio following outflows. When assets are less liquid, liquidation costs are higher therefore decreasing net asset value available for remaining investors. Indeed, Goldstein et al. (2017) and Feroli et al. (2014) show that investors' flows are particularly sensitive to bad performance of funds investing in less liquid assets such as corporate bonds unlike for equity funds (Ippolito (1992), Sirri \& Tufano (1998) among others). Given the growing size of the asset management industry, the question about the effects of funds' inflows and outflows on asset price dynamics is especially acute. Several studies (e.g., Warther (1995), Edelen (1999)) find that aggregate mutual funds' flows affect contemporaneous stock returns. Coval and Stafford (2007) show that large inflows and outflows of funds are able to exert price pressures in such a liquid market as the U.S. equity market. Greenwood and Thesmar (2011) showed that US stocks largely held by mutual funds were more fragile due to the concentration in their ownership and hence more volatile than other assets. Such factors are likely to be even stronger in the corporate bond market given its low liquidity and low depth in comparison to equity markets. However, there are very few studies analysing corporate bond market since data are less accessible and more difficult to work with.

In this paper, we analyze the effects on the corporate bond market exerted by the French bond and mixed mutual funds (French bond funds to simplify, or FBF, from now on). Indeed, these funds domiciled in France have become a major player in the financial markets as their assets under management (AUM) reached $€ 638$ bn in 2017. We use Bank of France's data on funds' bond holdings that provide us with the amount held by the FBF in each bond on a monthly basis from July 2011 to December 2017. We also have monthly data on the total net flows of these funds during the period. Among all the bonds held by the FBFs, we retain those issued by French companies. Indeed, we concentrate on the French corporate bond market for two reasons: (i) the substantial home bias makes French issuers predominant in the FBFs' portfolio; (ii) the lower liquidity of the corporate bond market compared to that of sovereigns or financials. These two reasons make the French corporate market the most likely to be affected by FBFs flows.

Given our bond-level dataset, we seek to identify the effect of aggregate fund flows on individual bond yields while controlling for bond characteristics. More specifically, we state five hypotheses about the responses of bond yields to net flows of funds at a bond-level. First, we verify that flows in and out of mutual funds affect corporate bond yields. This question has been extensively studied for equity markets, and numerous studies document a positive relationship between aggregate fund flows and contemporaneous equity market returns (Warther,1995; Edelen, 1999; Edelen and Warner, 2001) for the U.S. ; Ben-Raphael et al. (2011) for Israel). Second, we test for a concave relationship between fund 
flows and bond prices that may stem from the low liquidity nature of corporate bonds. Namely, we want to determine if outflows affect bond yields to a greater extent than inflows. Asymmetric effects are found by the IMF (2015), but they depend on the analyzed market: outflows have a greater effect for equity and bond funds invested in emerging markets and U.S. municipal bonds; no or limited effect for U.S. equity and high-yield bonds. Third, we test if the impact on yields due to the funds' flows is stronger for the bonds that funds hold a larger share of. The results confirm these three hypotheses. First, net fund flows do have an effect on bond yields. Second, the magnitude of the yield change is significantly higher in case of outflows than inflows. Third, the effect is stronger for those bonds that are held by funds to a larger extent.

We also test for two additional hypotheses. First, we investigate if bond liquidity premium is affected by redemptions and find some evidence that the yields of less liquid bonds are more sensitive to redemptions. Moreover, our data show that when facing redemptions, funds tend to sell all bonds regardless of their liquidity. Previous studies (Manconi et al. (2012), Chernenko and Sunderam (2016), Jiang et al. (2018)) analysed what asset classes are sold the most during redemption periods and found that outflows touch all asset classes but particularly the most liquid ones (cash-like securities, government bonds, etc.). However, they did not did not study price effects across asset classes. Second, we want to know if the bonds the most held by the funds are more or less sensitive to financial stress by introducing interactive variables reflecting financial stress in the regression. IMF (2015) suggests an amplification effect that may be due to funds' need to sell these bonds during turbulent times. Our findings on the adverse effect of greater ownership concentration on the bond yields show some evidence of an amplifying effect however the result is very sensitive to econometric specifications.

This paper contributes to the literature on mutual funds in three main ways. First, we study the impact on the corporate bond market of mutual funds flows, whereas the bulk of literature focus on their effect on the equity market (Warther,1995; Edelen, 1999; Edelen and Warner, 2001; Ben-Raphael et al., 2011). In fact, Goldstein et al. (2016) also study corporate bond funds but from a different perspective as they analyze the links between flows and funds' performance. Their results show that corporate bond funds' flows are more sensitive to bad performance than equity funds' flows, especially for funds with less liquid assets, which is a source of potential fragility.

Second, we use bond-level data instead of aggregate bond market data to analyze the price pressure effects. This allows us to control for other factors determining bond yields, thus providing a more robust estimation of the effect of fund flows on bond prices. Few studies use security-level data. Coval and Stafford (2007) employ security-by-security holdings at a fund-level and show that sudden increases/decreases in net flows to funds exert significant price pressure in U.S. equity markets. Manconi et al. (2012) focus on bond-level holdings of mutual fundsin order to study how institutional investors contributed to the propagation of the 2008 crisis from securitized to corporate bonds.

A third contribution is to study a market different from the U.S. Almost all the above-mentioned papers deal with the U.S. markets due to an easy access to data and good data quality. However, U.S. markets are special in the sense that they are largely open to many international investors. A smaller national market, like the French one, is interesting to study because domestic funds may hold a larger part of the locally issued bonds due to a persisting home bias. Moreover, French investment funds have become important in the euro area financial landscape, as they now rank fourth behind Luxembourg, Germany and Ireland, holding $10 \%$ of the all euro area funds' assets (Ponsart and Salvio, 2018). To our best knowledge, only Bellando and Tran-Dieu (2011) and Jondeau and Rockinger (2004) studied French mutual funds, but they focus on the flow-performance relationship in French equity funds. Bellando and Tran-Dieu (2011) find a convex relation between current net flows and past relative performance. More specifically, good past performance attracts more investors but bad past performance does not lead to significant fund outflows, which is the same kind of result as in the American case but with smaller magnitude. 
The remaining paper is structured in the following way. Section 2 describes the data and gives some key statistics about the bonds held by the FBF. In Section 3, we discuss the hypotheses about the impact of funds' holdings on the corporate bond market and the methods to test them econometrically. Section 4 presents the econometric results. Section 5 provides robustness checks. Section 6 concludes.

\section{Data and Stylized Facts}

We rely on a database provided by the Bank of France Statistics Department that reports all the bond holdings by all the mutual funds domiciled in France. The frequency is monthly, and the time period spans from July 2011 to December 2017. This database is detailed at the bond-level but not at the fund level, as it only supplies the total holdings of all funds for each bond.

\subsection{An overview of the whole FBFs' bond portfolio}

The database includes the bond holdings of two types of investment funds: (i) the bond funds that invest mainly in bonds by definition and (ii) the mixed funds that invest in a mix of bonds and other assets. The evolution of their net assets and bond holdings are depicted in Figure 1 . Bond funds have less assets under management than mixed funds (€281bn vs. $€ 357$ bn in December 2017), but own nearly twice more bonds (€139 bn vs. €78 bn).

As we do not try to distinguish the two types of funds in this paper, we aggregate all the holdings by the two categories of funds, and refer to them as the French bond funds (FBF) in the following. Taken together, the FBFs' net assets amounted to $€ 638$ bn at the end of 2017 including $€ 217$ bn invested in bonds. Assets under management by bond and mixed funds represent approximately half of the assets of all investment funds in France (Ponsart and Salvio, 2018).

Figure 1. Total net assets and total bond holdings of the bond and mixed funds, in billions euros

Total net assets

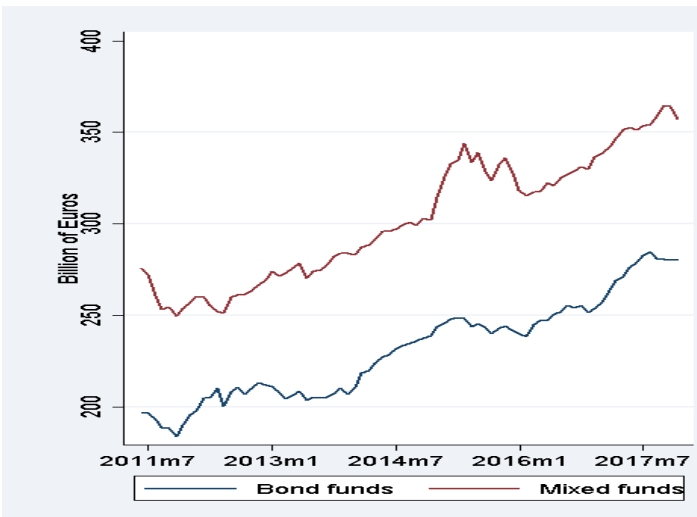

Bond holdings

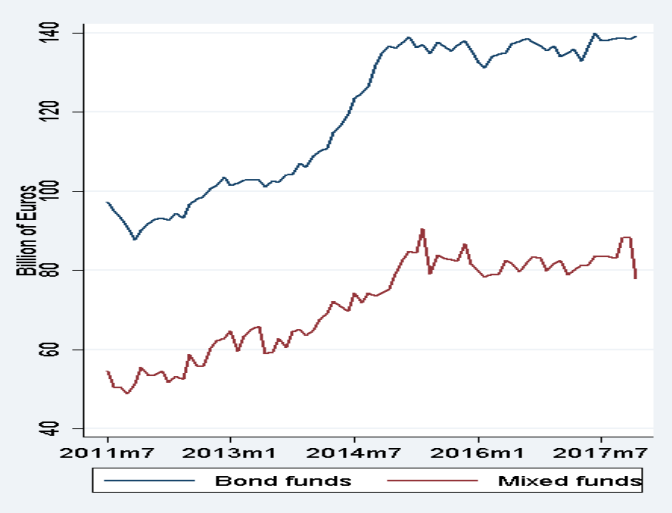

Source: Webstat, Banque de France

France is the main investment destination of the FBF, attracting $27 \%$ of the total assets on average over the period. Not surprisingly, the share of the French securities in the FBF's portfolio reached its highest share, 30\% at the peak of the euro area crisis in June 2012 (Figure 2). The home bias then receded gradually with the share of French bonds decreasing to $25 \%$ in December 2017. Among the euro area countries, Italy, Germany and Spain are the preferred investment destinations, making up to $30 \%$ of the portfolio. On the whole, $76 \%$ of the bonds held by the FBF are issued by European Union entities. The share of emerging countries is limited to $5 \%$ of the total. 
Figure 2. Bond holdings of the FBF (mixed and bond funds combined) by issuer country, in \%

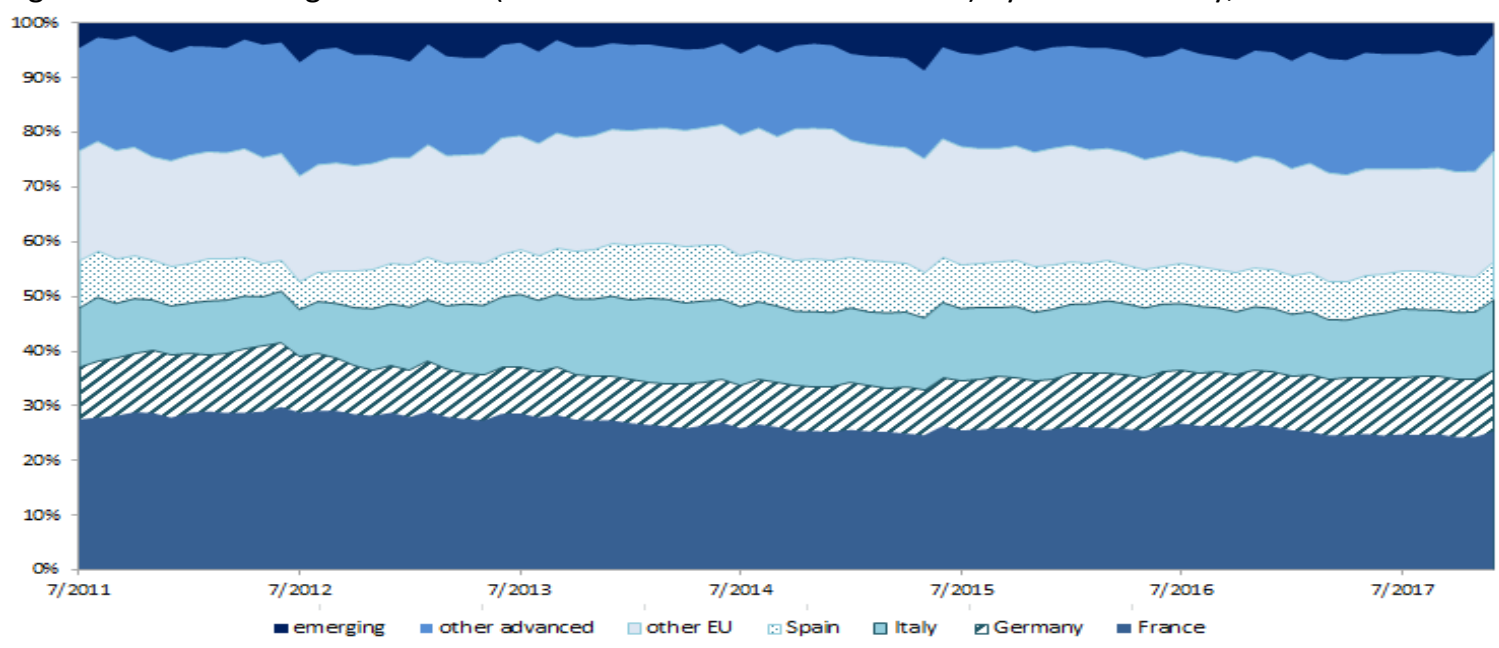

Corporate bonds amount to 38\% of the FBF's home portfolio, or $€ 21$ bn in December 2017 (Figure 3). This category is just behind the French sovereign bonds that account for about half of the home portfolio. The rest of the bond holdings are issued by financial institutions. If a market may be affected by the FBF's behavior, the French corporate bond market is the most likely candidate for two reasons: (i) the FBF hold a substantial share of this market (see next section); (ii) the French corporate bond market is rather narrow and little liquid.

Figure 3. French bonds held by the FBF by sector, in billions of euros.

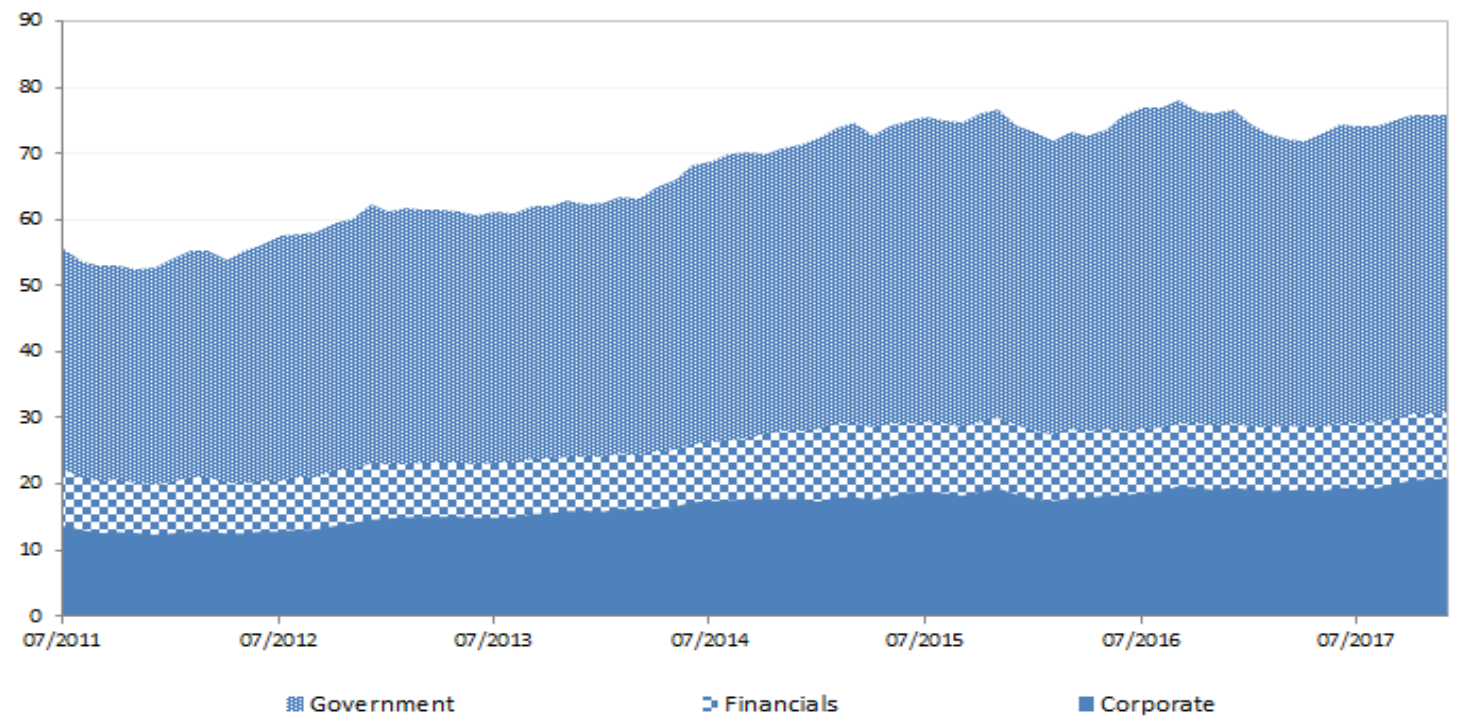

2.2 Selection of the sample of corporate bonds and bond-specific variables

The sample consists of 461 corporate bonds held by the FBF. These bonds are issued in EUR by 198 French firms. The data covers the period from July 2011 to December 2017 for which the holdings of the FBF are reported on a monthly basis. The number of bonds in the sample varies through time because all of them are not alive simultaneously as some are not yet issued while others have already matured. These bonds are selected on the grounds that (i) their yields are available on Bloomberg over the period and they are either (ii) reimbursed at maturity, or (iii) callable, meaning that the issuer has an option to reimburse it before maturity at predetermined periods of time, or (iv) perpetual. We exclude 
convertible bonds because their price is strongly driven by the evolution of the stock market and another econometric specification would be necessary to explain their yields.

The dataset includes two broad categories of data: specific to each bond and macro data. We summarize all the data below. At the bond-level, for each bond $i$ identified by its ISIN, we consider the following variables:

(i) outstanding amounts of bonds held by the FBF in market value (sum of bond $i$ at time $t$ held by both bond and mixed mutual funds), denoted $H_{i, t}$, that are provided by the Bank of France Statistics Department;

(ii) yield to maturity $y_{i, t}$, market price $P_{i, t}$, bid $P_{i, t}^{b}$ and ask $P_{i, t}^{a}$ prices, all extracted from Bloomberg; we then calculate the bid-ask spread as $\operatorname{Liq}_{i, t}=100 *\left(P_{i, t}^{b} / P_{i, t}^{a}-1\right)$ used as a proxy for (il)liquidity;

(iii) main bond characteristics: issued volume $\left(\mathrm{Vol}_{i}\right)$, issue and redemption dates, issue price $\left(P_{i}^{0}\right)$ coupon and bond type (at maturity, callable, or perpetual) and payment rank obtained from Bloomberg. We also extract the 5-year probability of default calculated by Bloomberg. From the redemption date, we calculate the residual maturity by counting number of months left before redemption. In order to avoid dropping perpetual bonds from the regression, we set their maturity arbitrarily at 50 years.

(iv) We compute the share $w_{i, t}$ owned by the FBFs in the market of each bond $i$. To do so, we divide the holdings $H_{i, t}$ by the outstanding amount of each bond. The latter is equal to the amount issued $\mathrm{Vol}_{i}$ multiplied by the current market price $P_{i, t}$, relative to the issue price $P_{i}^{0}$ :

$w_{i, t}=\frac{H_{i, t}}{\operatorname{Vol}_{i} P_{i, t} / P_{i}^{0}}, 0<w_{i, t}<1$

At the macro-level, we add macroeconomic variables common to all bonds such as interest rates: the French 10-year sovereign bond rate, the 3-month Euribor interest rate, the volatility of stock price indexes, the VIX for the US (S\&P500) and the Vstoxx for the European Union (Eurostoxx 50), that are extracted from Bloomberg.

\section{Relative net inflows into the FBFs}

We extract the net flows entering into the funds $F_{t}$ (either positive or negative) and the total funds' net assets under management $A_{t}$ from Webstat, Banque de France online database. We then take these flows as a percentage of the total net assets $A_{t-1}$ held by the FBF at the previous period. This relative flows ratio denoted $\phi_{t}$ is our variable of interest in the econometrics section:

$\phi_{t}=100 * \frac{F_{t}}{A_{t-1}}$

A striking feature of these flows is their great volatility, as they oscillate between positive and negative values all over the sample (Figure 4). As they are negative nearly $40 \%$ of the time, the potential adverse effects of withdrawals are a real issue to study. 
Figure 4. Relative flows into the FBF, in \% of AUM

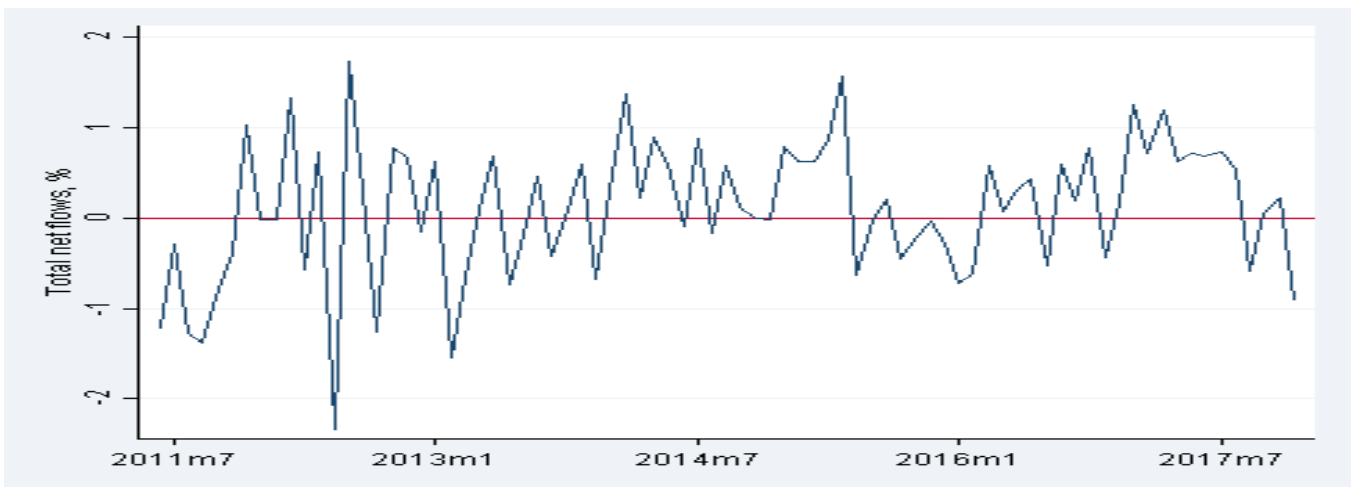

Note: Relative flows are defined as net flows divided by assets under management. Negative values correspond to redemptions Source: Webstat, Banque de France

\subsection{Main characteristics of the corporate bonds held by the FBF}

We now take a look at the main characteristics of bonds in our selected sample (Table 1). Several features stand out. First, bond maturity type evolved over the period: the share of bonds paid off at maturity notably declined to $42 \%$ in 2017, whereas they were predominant in 2011 (86\%). Meanwhile, the callable bonds gained in importance, as they now reach $48 \%$ of the FBF's portfolio against $10 \%$ in 2011. In the context of declining interest rates, many firms prefer to issue callable bonds, that they can reimburse in case the interest rates continue to fall; some companies may also expect an improvement in their rating in the future relatively to that obtained during the financial crisis; in both cases, firms are ready to pay a premium to issue callable bonds that will allow them to issue new debt with lower rates at the time of their choice.

Second, most bonds held by funds have a high pay-off priority: 81\% are either senior or first lien in 2017 and only $13 \%$ are junior subordinated. This structure is quite stable over the period. Third, risk-taking seems to be contained when considering the 5-year probabilities of default (PD). As expected, the PDs peaked at the height of the euro crisis in 2012, and then receded in the following years. The median is only $1.0 \%$ in 2017 , and $95 \%$ of bonds have a PD smaller than $4 \%$ at that time. These PDs are calculated by Bloomberg from a structural model involving different factors such as equity prices, amount of debt, etc. If we neglect the possible biases in calculating these PDs, the $1.0 \%$ median 5y-PD of the bonds in the FBFs' portfolio approximatively matches the $0.9 \%$ historical default rate of all investment grade corporates at this 5-y horizon, when calculated at the global level for the 1981-2017 period by Standard\& Poor's (2018).

Fourth, the FBFs' share of each bond market increased over the period, which is in line with the development in the total fund holdings. The median share augmented from $6.7 \%$ up to $8.3 \%$. However, it varies significantly across the bonds: $5 \%$ of bonds have more than $33.5 \%$ of their outstanding value detained by the FBFs, and $5 \%$ of them, less than $0.6 \%$. Fifth, the yields to maturity declined over the period, as most interest rates did under the effect of the ECB's asset purchase programme. Yields are quite spread: $5 \%$ of them are below $-0.1 \%$ while $5 \%$ exceed $5.7 \%$, in 2017 . Lastly, the coupons slightly declined over the period, but this movement is much less pronounced than that of the yields: (i) contrary to the yields, the coupons are fixed over the life of the bond; hence as long as the bonds are not reimbursed, their coupons stay the same; as the bonds are long-term, the sample of bonds only slowly changes from one year to another, which explains the sluggish movements in the coupons; (ii) there were more and more callable bonds over the period, and those bonds must offer better coupons in order to compensate for their possible early pay-off at the decision of the issuer. 
Table 1. Characteristics of the corporate bonds held by the FBF in the sample

\begin{tabular}{|c|c|c|c|c|c|c|c|c|c|}
\hline \multirow[t]{2}{*}{ Year } & \multicolumn{3}{|c|}{ (1) Maturity type, in \% } & \multicolumn{3}{|c|}{ (2) Payment rank, in \% } & \multicolumn{3}{|c|}{ (3) Probability of default, in \% } \\
\hline & At maturity & Callable & Perpetual & 1st lien & senior & sub & p5 & p50 & p95 \\
\hline 2011 & 85.97 & 9.75 & 4.18 & 5.58 & 79.10 & 14.62 & 0.53 & 2.29 & 7.69 \\
\hline 2012 & 85.71 & 9.90 & 3.77 & 5.34 & 80.31 & 13.20 & 0.64 & 2.87 & 8.82 \\
\hline 2013 & 80.38 & 14.06 & 5.05 & 6.03 & 78.02 & 13.13 & 0.40 & 1.49 & 5.58 \\
\hline 2014 & 70.36 & 22.04 & 6.91 & 9.51 & 72.25 & 13.45 & 0.30 & 1.28 & 4.78 \\
\hline 2015 & 60.05 & 30.84 & 8.39 & 10.98 & 69.40 & 14.09 & 0.38 & 1.42 & 5.58 \\
\hline 2016 & 52.15 & 38.67 & 8.55 & 10.80 & 70.06 & 13.58 & 0.55 & 1.80 & 7.30 \\
\hline 2017 & 42.78 & 47.75 & 9.13 & 12.24 & 68.61 & 13.45 & 0.27 & 1.00 & 3.96 \\
\hline \multirow[t]{2}{*}{ Year } & \multicolumn{3}{|c|}{ (4) Bond share held by FBF in \% } & \multicolumn{3}{|c|}{ (5) Yield to maturity, in \% } & \multicolumn{3}{|c|}{ (6) Coupon, in \% } \\
\hline & p5 & p50 & p95 & p5 & p50 & p95 & p5 & p50 & p95 \\
\hline 2011 & 0.69 & 6.72 & 26.10 & 1.86 & 4.10 & 9.99 & 3.18 & 4.88 & 8.50 \\
\hline 2012 & 0.72 & 6.74 & 24.24 & 0.84 & 2.91 & 11.08 & 3.00 & 4.82 & 8.50 \\
\hline 2013 & 0.67 & 7.64 & 25.03 & 0.61 & 2.39 & 7.90 & 2.63 & 4.75 & 8.50 \\
\hline 2014 & 0.64 & 8.42 & 31.83 & 0.41 & 1.87 & 7.07 & 2.50 & 4.63 & 8.50 \\
\hline 2015 & 0.71 & 8.56 & 35.78 & 0.21 & 1.62 & 7.15 & 1.88 & 4.50 & 8.50 \\
\hline 2016 & 0.73 & 8.37 & 35.32 & -0.07 & 1.29 & 7.81 & 1.75 & 4.25 & 8.50 \\
\hline 2017 & 0.59 & 8.30 & 33.47 & -0.08 & 1.24 & 5.72 & 1.13 & 4.00 & 7.88 \\
\hline
\end{tabular}

Note: The sample consists of 461 corporate bonds issued in EUR by about 200 French firms and held by the FBF from July 2011 to December 2017. These bonds are selected on the ground that (i) their yields are available in Bloomberg over the period and (ii) they are either reimbursed at maturity, callable or perpetual.

\section{The effect of the CSPP on bond yields}

The European Central Bank (ECB) announced its "corporate securities purchase programme" (CSPP) in March 2016 and started regularly purchasing corporate bonds in June 2016. This measure is included in the asset purchase programme (APP) that aimed at reducing interest rates in the euro area and follows the public securities purchase programme (PSPP) that focused on sovereign bonds. $€ 130$ bn of European corporate bonds were progressively bought under the CSPP by December 2017, as shown in Figure 5. Most of the purchases are made on the secondary market. The ECB publishes the information on country breakdown of purchases on a semi-annual basis starting from Q3 2017. The bonds issued by French firms make up to about 30\% of the purchased amount in Q3 2017 and 29\% in Q1 2018.

The CSPP targets bonds issued by the non-financial firms domiciled in the euro area that meet the following eligibility conditions: they must be (i) investment-grade; (ii) issued in euros; (iii) residual maturity ranging between 6 months and 31 years; (iv) yields higher than the ECB deposit facility rate. These conditions exclude the perpetual, but not the callable bonds. The set of "CSPP-eligible bonds" defined by the above conditions is a subset of those accepted as collateral in the ECB monetary policy operations, named the ECB-eligible bonds.

In our sample, there are 102 ECB-eligible bonds identified using the list of the ECB-eligible securities available on the ECB's site; four of them do not meet the conditions of maturity or have their yields-tomaturity below the deposit facility rate. Hence, we end up with 98 CSPP-eligible ISIN. From this set, 67 bonds had been actually purchased by the Eurosystem in December 2017, (versus 61 in June 2017), as we can see from the list of securities held by the ECB for the period beginning in June 2017 on the ECB 
website. ${ }^{1}$ Among the 6 new bonds purchased between June and December 2017, 4 were issued after June 2017, so probably bought on the primary market.

The purchased bonds are not different from the eligible ones that have not been purchased when we compare their yield or the issuer's probability of default. The only difference lies in their issue date (and hence in the residual maturity): the purchased bonds are generally more recently issued (by three years on average, though with a large variance). More recent bonds are indeed more likely to be present on the secondary market than older ones. However, as all CSPP-eligible bonds are susceptible be purchased at any time by the Eurosystem, we do not differentiate them from the subset of bonds that have been actually bought. Therefore in our econometric estimations, we will consider the whole set of the CSPPeligible bonds, and not those actually purchased.

Figure 5. ECB holdings of corporate securities under the CSPP, in billion euros

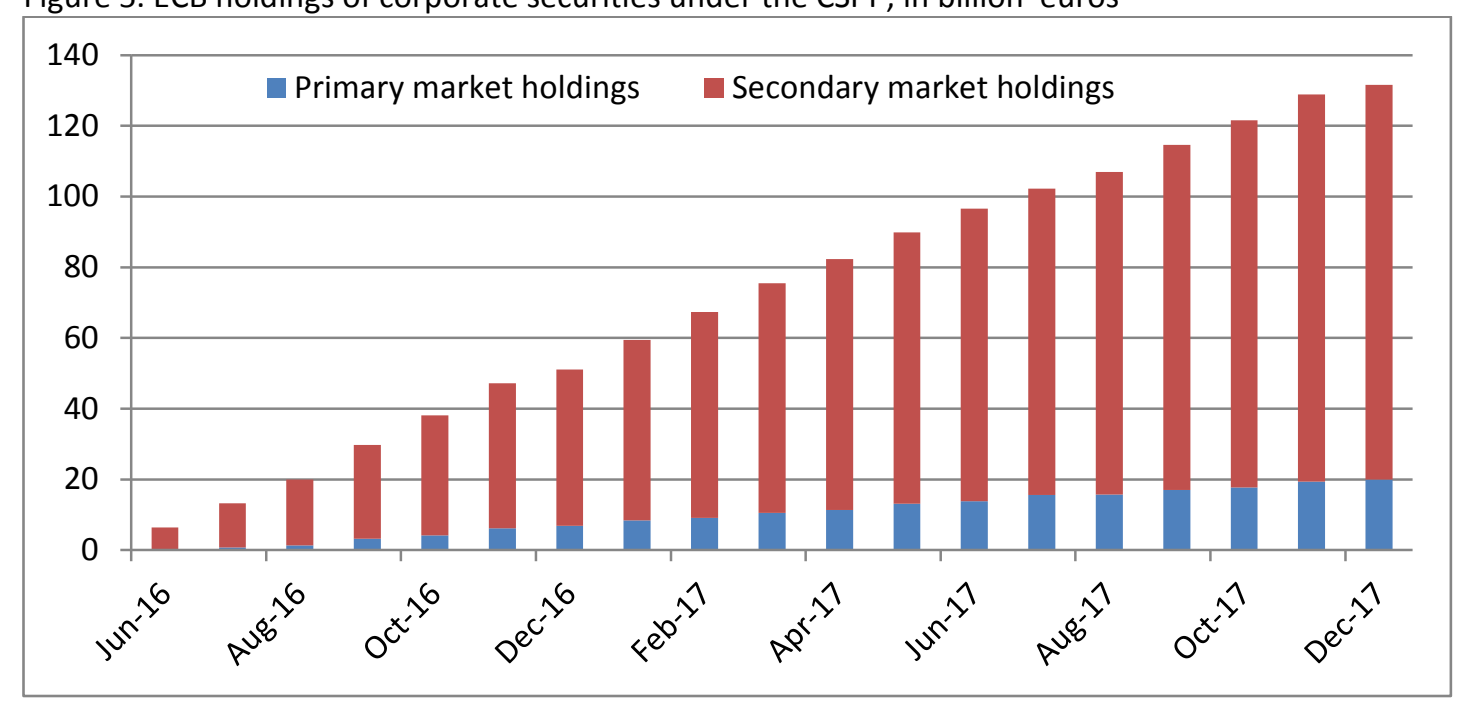

Source: ECB website.

As the goal of the programme is to facilitate credit conditions for firms, it should have an impact on bond yields. De Santi et al. (2018) find several beneficial effects such as a decrease in the corporate bond spreads, a development in the issuances and the lengthening of maturities using a euro area sample. They also showed that the effect of the CSPP on spreads was mostly concentrated over the two weeks following the announcement in March 2016. The decline in spreads concerned all bonds, whether eligible or not, though the move was stronger on the eligible ones. Abidi and Miquel-Flores (2018) reach the same conclusion by an econometric analysis focusing on the bonds near the BBB-rating, which is the lower limit for investment-grade bonds.

\section{Hypotheses and methodology}

We rely on regressions at the bond level to measure the impact of the flows entering the funds on the corporate bond market.

\subsection{Defining the benchmark regression}

We retain the bond yield-to-maturity as the left-hand side (LHS) variable in the regressions, as the spread would not be a consistent time-series variable. To see that, let us consider a given bond $k$ with

\footnotetext{
${ }^{1}$ The CSPP started in June 2016, but the ECB started publishing its holdings on a weekly basis only in June 2017. A number of checks of holdings in June, September and December 2017 suggests that most securities are consistently held from one period to the other.
} 
residual maturity $M$ at time $t$. At time $t$, its spread is equal to its yield to maturity minus the risk-free rate of same maturity, which gives the usual formula:

$s_{k, t}=y_{k, t}-r_{M, t}$ where $s_{k, t}$ denotes bond $k^{\prime} \mathrm{s}$ spread at time $\mathrm{t}, y_{k, t}$ bond $\mathrm{k}^{\prime} \mathrm{s}$ yield to maturity in $\mathrm{t}$, and $r_{M, t}$ the risk free rate of same maturity $M$.

However, the same formula does not hold at time $t+1$. Indeed, at time $t+1$, bond $k$ has a maturity $M-1$, so its yield should be compared to $r_{M-1, t+1}$. This could be an acceptable proxy of the spread if the maturity gap between the bond and the risk-free rate is only a few months. Indeed, Manconi et al. (2012) that worked on similar bond data for the US were able to use the spread as the LHS variable in their regression, as their time period spans only over a few months in year 2007. In our case, as the data cover a 7-year span, maturities cannot be considered as constant. To overcome this problem, we use the bond yields as the LHS variable and add three control variables on the right-hand side: (i) a long-run risk-free rate (the $10 y$-sovereign rate); (ii) a 3-month risk-free rate and (iii) bond residual maturity that evolves over time.

In order to capture the impact of the FBF on the bond market, a preliminary step is to run a regression explaining the corporate bond yields by their usual factors. We retain five broad categories of explanatory variables to account for the formation of corporate bond yields: (i) a risk-free rate and time to maturity; (ii) credit risk; (iii) risk aversion; (iv) liquidity premium; (v) intrinsic characteristics of bonds, such as covenants, maturity-type or pay-off seniority.

Let us briefly review these determinants and their expected signs for a bond yield $y_{i, t}$ where the subscript $i$ stands for bond $i$ and $t$ is the current time.

First, risk-free rates are key factors in bond pricing. Strictly speaking, the bond yield should be related to the risk-free rate $r_{\tau, t}$ of the exact same maturity in order to avoid any distortion due to the term structure. As maturity varies over time, we cannot put in the regression a risk-free rate of the exact same maturity, we then retain two risk-free interest rates of long and short maturity as explanatory variables: the French 10-year sovereign bond rate and the 3-month EURIBOR. We also include residual maturity in the regression since bonds with longer maturity are expected to offer higher yields.

Second, bond yields depend on credit risk which in turn is determined by the borrower's probability of default, its expected recovery rate, time to maturity and risk-free rates. Here, we use the issuer's probability of default calculated by Bloomberg as a proxy for credit risk.

Third, even if probabilities of default and recovery rates are constant, the risk premium may still vary due to a change in risk aversion. This happens, for example, in times of financial stress when all bond spreads tend to rise for any given rating. These times of financial stress can be identified by the increase in the implied volatility in the global stock markets, represented by the Vstoxx or the VIX. A number of studies have adopted the VIX as a measure of "financial stress" and risk aversion (see, for example, Coudert et al., 2013; Rey, 2016).

Fourth, bond yields also incorporate a non-default component related to the market liquidity (Longstaff et al. 2004; Han and Zhou, 2011; Bao et al., 2011). We use the bid-ask spread as a measure of the market illiquidity. All the four aforementioned factors have positive expected signs: risk-free interest rates, residual maturity, probability of default, equity market volatility and illiquidity are supposed to mitigate bond prices and therefore raise their yield-to-maturity.

Next, we take into account the intrinsic features of bonds by adding the coupon to the explanatory variables, as well as dummies standing for the maturity type and the payment rank. The maturity type distinguishes the bonds paid at maturity, perpetual or callable. We expect the perpetual and callable bonds to have higher yields than the standard ones; pay-off priority can also play a role. As these intrinsic features are fixed over the whole life of the bond, they cannot enter a fixed effect regression. 
Lastly, we account for the effects of the CSPP on bond yields. We therefore consider the dummy variable $\operatorname{CSPP}_{i t}$ that is equal to 1 for the 98 CSPP-eligible bonds in the sample at the time of the CSPP announcement in March 2016. We also add a time indicator function CSPP_All $t_{t}$ set to 1 at the time of the CSPP announcement in March 2016 and zero elsewhere. This variable is meant to capture the effects on all bonds across the board of the CSPP announcement.

We gather all the above explanatory variables in a benchmark model explaining the bond yields.

$y_{i t}=\sum_{m=1}^{M} \zeta_{j} X_{m, t}+\sum_{k=1}^{K} \rho_{k} B_{k, i t}+\sum_{h=0}^{H} \tau_{h} \operatorname{CSPP}_{i, t-h}+\sum_{h=0}^{H} \theta_{h} \operatorname{CSPP}_{A L L_{t-h}}+\mathrm{c}_{i}+\varepsilon_{i, t}$

(Benchmark Model)

where $y_{i, t}$ is bond $i$ 's yield-to-maturity at the end of month $t, X_{m, t}$ denotes the set of $M$ control variables common to all bonds, such as the sovereign bond rate, the short-term interest rate, the volatility in stock markets on average in month t; $B_{k, i t}$ stands for the group of $K$ variables specific to bond $i$ such as residual maturity, probability of default, lagged liquidity and constant intrinsic factors; $\zeta_{j}, \rho_{k}$ are coefficients to estimate, common to all bonds, and reflecting the sensitivity of the bond yield to the different variables, $c$ is an intercept and $\varepsilon_{i, t}$ the residual of the equation.

\subsection{Hypothesis 1: Net flows into the FBF affect corporate bond yields}

First, we want to determine whether money entering (or exiting) the funds exerts an impact on the bond yield. Indeed, large inflows in the FBF may provoke a surge in demand for corporate bonds and may release a positive signal concerning the market evolution. As bond supply does not adjust simultaneously, this creates an upward price pressure, mitigating their yield. Conversely, investors' redemptions from funds would have the opposite effect. To test this possible effect, we add relative net flows entering into the FBF to the benchmark regression once the relevant control variables have been selected.

$y_{i, t}=\sum_{j=1}^{J} \gamma_{j} C_{j, i, t}+\alpha \phi_{t}+c_{i}+\varepsilon_{i, t}$

(Model 1)

where $C_{j, i, t}$ gathers the set of all selected control variables, common to all bonds, bond specific and the CSSP dummies; $\phi_{t}$ is the net flows in the FBF as a percentage of the total net assets of the funds at the previous period, as stated in Equation (2).

The null hypothesis is of no impact on the bond yields of the flows. We test it by a Student test on the estimated coefficient $\widehat{\alpha}=0$. If we reject the null, then we check that the impact on yields is negative $(\widehat{\alpha}<0)$. In this case, we accept the alternative hypothesis:

\section{$\left(\mathrm{H} 1_{1}\right)$ : "Net flows have an impact on bond yields"}

\subsection{Hypothesis 2: Redemptions affect bond yields to a larger extent than inflows}

We then test for a possible asymmetric effect. The question is to determine if investors' withdrawals from FBF have more adverse effects in increasing bond yields than inflows have favorable ones. This would happen if funds have to sell large amounts of bonds on the secondary market in case of redemptions, as we know this secondary market is rather illiquid. On the contrary, the secondary market would not be so affected by inflows, since funds can also purchase newly issued securities on the primary market. In theory, funds can use their cash to avoid selling their assets massively in times of redemption, but it is not necessarily the case. To test for this asymmetric effect, we introduce the negative part $\overline{\phi_{t}^{-}}$of the relative flows into the regression, calculated as $\phi_{t}^{-}=\phi_{t}$ if $\phi_{t}<0 ;=0$ elsewhere.

$y_{i, t}=\sum_{j=1}^{J} \gamma_{j} C_{j, i, t}+\alpha \phi_{t}+\alpha^{-} \phi_{t}^{-}+c_{i}+\varepsilon_{i, t}$

(Model 2) 
The null hypothesis is an impact of the same magnitude on yields, equivalent to $\widehat{\alpha^{-}}=0$. If the null is rejected, we check the sign of the $\widehat{\alpha-}$ coefficient. A negative sign indicates a larger response of bond yields to withdrawals than to positive inflows. The alternative hypothesis is then accepted.

\section{$\left(\mathrm{H} 2_{1}\right)$ : "Outflows have an impact on bond yields of greater magnitude than inflows "}

\subsection{Hypothesis 3: The impact of net flows depend on funds' market share in bonds}

Next step is to capture the effect of flows with respect to the funds' market share in a particular bond; more specifically, we want to know if this impact is stronger on the bonds that are detained in larger amounts by the FBF. In other words, we have to verify if the larger the share of the FBF in the bond market, the higher the impact of inflows or withdrawals. To test this, we add an interactive term into the regression, denoted $\phi_{t} w_{i, t-1}$ that is equal to the relative flows in the FBF $\phi_{t}$ multiplied by the share $w_{i, t-1}$ of the FBFs' holdings in the total amount of bond $i$ at the previous period. The share $w_{i, t-1}$, defined in Equation (1), is added into the regression as a control variable in order to properly test the interactive effect. It is taken with a lag in order to avoid any endogeneity issue. The equation to test is therefore the following:

$y_{i, t}=\sum_{j=1}^{J} \gamma_{j} C_{j, i, t}+\mu w_{i, t-1}+\alpha \phi_{t}+\alpha^{-} \phi_{t}^{-}+\beta \phi_{t} w_{i, t-1}+c_{i}+\varepsilon_{i, t}$

(Model 3)

The null hypothesis is that the impact of flows is the same whatever the holdings of the FBF in the bond market, which amounts to $\widehat{\beta}=0$. Here again, if we reject the null, we expect to find a negative sign on the $\widehat{\beta}$ coefficient, meaning that the presence of the FBF on the market amplifies the response to inflows or outflows. Our alternative hypothesis is thus:

$\left(\mathrm{H}_{1}\right)$ : "The more a bond is detained by the FBF, the higher the impact of net flows on its yield"

As there could also be an asymmetric effect of the interactive variable, we also test for another version of Model 3 by introducing the negative part of the interactive variable. This lets the possibility that redemptions have a stronger impact on yields of the bonds largely held by the FBFs than the inflows.

$y_{i, t}=\sum_{j=1}^{J} \gamma_{j} C_{j, i, t}+\mu w_{i, t-1}+\alpha \phi_{t}+\alpha^{-} \phi_{t}^{-}+\beta \phi_{t} w_{i, t-1}+\beta^{-} \phi_{t}^{-} w_{i, t-1}+c_{i}+\varepsilon_{i, t} \quad$ (Model 3')

The null hypothesis is then $\hat{\beta}=0 \cap \hat{\beta}^{-}=0$. If we reject it, and moreover find $\hat{\beta} \leq 0$ and $\hat{\beta}^{-}<0$, redemptions have a stronger impact on yields of the bonds largely held by the FBFs. In other words, ownership by funds matter more in times of withdrawals. Note that this is also another way to identify an asymmetric effect between inflows and redemptions.

$\left(\mathrm{H}^{\prime}{ }_{1}\right)$ : "The more a bond is detained by FBF, the higher the impact of outflows on its yield"

\subsection{Hypothesis 4: Fund redemptions have an impact on liquidity premia}

Withdrawals from funds may also affect bonds liquidity premia depending on types of assets that funds sell. Two explanations are possible. First, when facing investors' outflows, funds sell certain types of assets first. As suggested by Choi and Shin (2016) and Jiang et al. (2018) funds sell different asset classes (cash-like securities, government bonds, corporate bonds, etc.) to a different extent with more liquid types of securities being liquidated more massively. The other reason can be that while funds sell various assets, securities are affected differently with respect to their (il)liquidity. To test for this effect, we add an interactive variable $L i q_{i, t-1} \phi_{t}^{-}$equal to the lagged liquidity proxy $L i q_{i, t}$ multiplied by the negative part of the funds flows $\phi_{t}^{-}$in the regression. This interactive variable is added on the top of the lagged liquidity proxy that is already included in the control variables. The control liquidity variable then captures the standard effect of liquidity, that more illiquid bonds have lower price and hence higher yields. By adding this interactive variable, we stipulate that two different effects of liquidity are at play 
in times of withdrawals: the standard effect and the interactive effect resulting from the funds' behavior.

$y_{i, t}=\sum_{j=1}^{J} \gamma_{j} C_{j, i, t}+\mu w_{i, t-1}+\alpha \phi_{t}+\alpha^{-} \phi_{t}^{-}+\beta \phi_{t} w_{i, t-1}+\beta^{-} \phi_{t}^{-} w_{i, t-1}+\lambda L i q_{i, t} \phi_{t}^{-}+c_{i}+\varepsilon_{i, t}$

(Model 4)

The null is of no impact on liquidity premia of redemptions $\Leftrightarrow \hat{\lambda}=0$. If rejected, we conclude that redemptions result in distortions in the liquidity premia. The sign of the $\lambda$ coefficient will give us the sense of this effect, either to increase liquidity premia or to mitigate it.

$\left(\mathrm{H} 4_{1}\right)$ : "Redemptions from funds have an impact on bond liquidity premia"

\subsection{Hypothesis 5: Ownership by FBF affect bond yields in periods of financial stress}

We also want to know if a bond largely detained by funds is more fragile in periods of stress. To tackle this issue, we introduce an interactive term denoted $\sigma_{t} w_{i, t-1}$ in the former regression equal to the volatility of stock markets $\sigma_{\mathrm{t}}$ multiplied by the share of bonds $i$ owned by funds at the previous period: $w_{i, t-1}$. The volatility in the global stock market $\sigma_{t}$ is measured either by the Vstoxx or the VIX. This interactive variable is introduced in addition to the control variable $\sigma_{t}$ in order to capture differentiated response to financial stress depending on ownership by funds. $y_{i, t}=\sum_{j=1}^{J} \gamma_{j} C_{j, i, t}+\mu w_{i, t-1}+\alpha \phi_{t}+\alpha^{-} \phi_{t}^{-}+\beta \phi_{t} w_{i, t-1}+\beta^{-} \phi_{t}^{-} w_{i, t-1}+\lambda L i q_{i, t} \phi_{t}^{-}+\omega \sigma_{t} w_{i, t-1}+$
$c_{i}+\varepsilon_{i, t}$

The null hypothesis is $\widehat{\omega}=0$. If rejected, we accept the alternative $\left(\mathrm{H} 5_{1}\right)$.

$\left(\mathrm{H} 5_{1}\right)$ : "The bond yield response to financial stress depends on the ownership of this bond by funds"

According to the estimated sign of $\widehat{\omega}$, we will conclude to ownership by funds making the market more sensitive to financial stress if $\widehat{\omega}<0$ or more resilient if $\widehat{\omega}>0$.

\section{Estimation results}

The regressions are run over the period July 2011 to December 2017. The panel is unbalanced because at a given period of time, some of the bonds are not yet issued and others are already payed-off. The regressions are performed on 390 individual bonds, instead of 461 in the initial sample, because the issuer's probability of default is not available for a number of securities.

\subsection{Benchmark regression with control variables}

We begin by running the regressions that only include the control variables. As a preliminary step, we perform a number of tests to determine the best specification. First, we use the Breush-Pagan-Lagrange test, which leads us to strongly reject the null hypothesis of no panel effects (ordinary least squares (OLS) against random effects). Second, following the Hausman test, we reject the null of random effects versus fixed effects at more than $99 \%$ confidence level; therefore we adopt a fixed effect approach. Third, Wald tests for heteroskedastcity also show that residuals are heteroskedastic. To correct this bias, we use Huber/White robust errors.

We hence retain the regression with fixed effects and correction of the coefficient standard errors for heterogeneity. Nevertheless, we also present random effects estimations in Table 2 as these regressions enable us to include constant bond-specific factors that provide a check for the consistency of the data.

All the coefficients of macro and bond-specific variables have the expected signs and are highly significant in all the regressions (Table 2). As regards the common determinants, the bond yields 
respond positively and significantly to the sovereign bond rate, the short-term interest rate and the volatility in the equity markets. Regarding the bond-specific variables, the residual maturity, the probability of default and the illiquidity proxy increase the bond yields as expected; the coefficients are significant at a $99 \%$ confidence threshold for all the variables.

Turning to the CSPP, we find a significant effect on the eligible bonds at the time of the announcement in March 2016. It causes their yield to fall approximately by 6-7 basis points in both regressions with fixed and random effects. Indeed, at the announcement time, as two coefficients are at play: for the eligible bonds (-24.45) and for all bonds (+18.59), they must be added to get the total impact on the eligible bonds. This result confirms those found by Abidi and Miquel-Flores (2018) and De Santis et al. (2018) on a euro area sample. We also evidence that the effects are significant up to 11 months after the announcement, which complements the results of the previous studies. The estimated lagged coefficients are all negative up to 11 months, showing that the CSPP did succeed in lowering the corporate bond rates for the set of eligible bonds; the average decline in yield amounts to $10 \mathrm{bp}$ over this 11-month period. The structure of the lags shows that the impact on yields was the strongest at the time of the announcement and peaked again four months after the effective implementation in June 2016. It then progressively wipes out before turning non-significant after one year. In the following, we therefore keep the dummy variables on the CSPP for eligible bonds with the 11 significant lags.

Regarding the CSPP non-eligible bonds, our results do not show a clear-cut effect, except that their yields tend to increase at the time of the CSPP announcement. This could be due to expectations of rising prices on the eligible bonds, leading investors to sell other bonds. Only the month of announcement is significant in the regression, none of the following 12 lags are; hence only the contemporaneous variable is reported in Table 2. Abidi and Miquel-Flores (2018) find similar results on non-eligible bond yields for the euro area, while evidencing positive effects of the CSSP through a rise in new issuances for all corporates. Taking into account all these results, we consider that there are no clear-cut evidence for the non-eligible bonds and thus remove the variable CSSP_all ${ }_{\text {it }}$ from the following regressions.

Regarding the random effects regressions, they just allow us to check the effect of the constant variables. We verify that callable bonds have higher yields than the others, by approximately 2 percentage points, due to the higher risk born by the holder. We also find that the higher the coupon, the higher the yield. Two other constant variable were not found significant in the regressions : (i) the dummy for perpetual bonds, as its effect may be captured by that of residual maturity that we have set to 50 years or these bonds; (ii) the payment rank, whose effect can be blurred by that of the coupon that differ across seniority. 
Table 2. Benchmark model: estimation of corporate bond yields with control variables

\begin{tabular}{|c|c|c|c|c|}
\hline \multirow[b]{2}{*}{ Long rate } & \multicolumn{2}{|c|}{ Fixed effects } & \multicolumn{2}{|c|}{ Random effects } \\
\hline & $0.6021^{* * *}$ & $0.5960^{\star \star \star *}$ & $0.6588^{* * *}$ & $0.6530^{* * *}$ \\
\hline & {$[0.0000]$} & {$[0.0000]$} & {$[0.0000]$} & {$[0.0000]$} \\
\hline \multirow[t]{2}{*}{ Short rate } & $0.6351^{* * *}$ & $0.6307^{* * *}$ & $0.7266^{* * *}$ & $0.7091^{* * *}$ \\
\hline & [0.0000] & {$[0.0000]$} & [0.0000] & [0.0000] \\
\hline \multirow[t]{2}{*}{ Vstoxx } & $0.0213^{* * *}$ & $0.0216^{\star * *}$ & $0.0248^{* * *}$ & $0.0250^{* * *}$ \\
\hline & {$[0.0001]$} & {$[0.0001]$} & {$[0.0000]$} & [0.0000] \\
\hline \multirow[t]{2}{*}{ VIX } & $0.0145^{* * *}$ & $0.0148^{\star \star *}$ & $0.0117^{* *}$ & $0.0122^{\star *}$ \\
\hline & [0.0055] & {$[0.0054]$} & [0.0183] & [0.0147] \\
\hline \multirow[t]{2}{*}{ Residual maturity } & $0.0101^{* * *}$ & $0.0098^{* * *}$ & $0.0041^{* * *}$ & $0.0040^{* * *}$ \\
\hline & {$[0.0024]$} & {$[0.0043]$} & [0.0058] & [0.0073] \\
\hline \multirow[t]{2}{*}{ Proba of default } & $0.2329^{* * *}$ & $0.2363^{\star * \star}$ & $0.2273^{* \star *}$ & $0.2306^{* * *}$ \\
\hline & {$[0.0000]$} & {$[0.0000]$} & {$[0.0000]$} & [0.0000] \\
\hline \multirow[t]{2}{*}{ Liquidity(-1) } & $0.6332^{* * *}$ & $0.6309^{* * *}$ & $0.6762^{* * *}$ & $0.6735^{* * *}$ \\
\hline & {$[0.0000]$} & {$[0.0000]$} & [0.0000] & [0.0000] \\
\hline \multirow[t]{2}{*}{ Coupon } & & & $0.4898^{\star * *}$ & $0.4859^{\star * *}$ \\
\hline & & & {$[0.0000]$} & [0.0000] \\
\hline \multirow[t]{2}{*}{ Callable } & & & $2.2150^{* * *}$ & $2.2232^{* * *}$ \\
\hline & & & {$[0.0000]$} & [0.0000] \\
\hline \multirow[t]{2}{*}{ CSPP } & & $-0.2445^{* * *}$ & & $-0.2650^{* * *}$ \\
\hline & & [0.0069] & & {$[0.0000]$} \\
\hline \multirow[t]{2}{*}{ cspp_1 } & & $-0.1690^{* * *}$ & & $-0.1911^{* * *}$ \\
\hline & & {$[0.0084]$} & & {$[0.0021]$} \\
\hline \multirow[t]{2}{*}{ cspp_2 } & & -0.0266 & & -0.0419 \\
\hline & & [0.6741] & & [0.4895] \\
\hline \multirow[t]{2}{*}{ cspp_3 } & & $-0.1308^{*}$ & & -0.1393 \\
\hline & & [0.0982] & & [0.1152] \\
\hline \multirow[t]{2}{*}{ cspp_4 } & & $-0.1636^{* *}$ & & $-0.1610^{* *}$ \\
\hline & & {$[0.0258]$} & & [0.0410] \\
\hline \multirow[t]{2}{*}{ cspp_5 } & & $-0.1264^{*}$ & & $-0.1281^{*}$ \\
\hline & & {$[0.0691]$} & & [0.0525] \\
\hline \multirow[t]{2}{*}{ cspp_6 } & & $-0.1174^{*}$ & & $-0.1254^{*}$ \\
\hline & & [0.0903] & & [0.0571] \\
\hline \multirow[t]{2}{*}{ cspp_7 } & & $-0.2317^{* * *}$ & & $-0.2523^{* * *}$ \\
\hline & & [0.0003] & & {$[0.0000]$} \\
\hline \multirow[t]{2}{*}{ cspp_8 } & & $-0.1745^{\star \star *}$ & & $-0.2233^{* * *}$ \\
\hline & & {$[0.0067]$} & & {$[0.0001]$} \\
\hline \multirow[t]{2}{*}{ cspp_9 } & & $-0.1007^{*}$ & & $-0.1368^{* * *}$ \\
\hline & & [0.0908] & & {$[0.0007]$} \\
\hline \multirow[t]{2}{*}{ cspp_10 } & & $-0.1209^{*}$ & & $-0.1868^{* * *}$ \\
\hline & & {$[0.0544]$} & & [0.0000] \\
\hline cspp_11 & & $-0.1087^{*}$ & & $-0.1622^{* * *}$ \\
\hline & & [0.0998] & & {$[0.0000]$} \\
\hline cspp_12 & & -0.0085 & & $-0.0744^{*}$ \\
\hline & & [0.9028] & & {$[0.0585]$} \\
\hline cspp_all & & $0.1859^{\star * \star}$ & & $0.1953^{* * *}$ \\
\hline & & {$[0.0014]$} & & {$[0.0000]$} \\
\hline R-squared & 0.5804 & 0.5813 & & \\
\hline Observations & 13,518 & 13,518 & 13,518 & 13,518 \\
\hline Number of isin_id & 390 & 390 & 390 & 390 \\
\hline
\end{tabular}

Note: Estimation of the Benchmark Model at the bond level with corporate bond yields as dependent variable. Long rate: French 10-y sovereign rate; short rate: 3-month Euribor; Prob of default: probability of default of each bond extracted from Bloomberg; Liquidity: bid-ask spread; Callable: dummies for this type of bonds. Hausman test show that fixed effects dominate the random effects regressions. CSPP is a dummy variable for all CSPP-eligible bonds at the announcement, March 2016. Cspp_X corresponds to $\mathrm{X}$ lag of the CSPP variable. Cspp_all is a dummy for all bonds in the sample at the announcement. Robust p-values in brackets are corrected for heterogeneity, ${ }^{* * *} p<0.01,{ }^{* *} p<0.05,{ }^{*} p<0.1$. 


\subsection{The Impact of net inflows in the FBF}

We start from the benchmark regression with fixed effects including only the control variables and add our variables of interest successively in the regression (Table 3). To test for the first hypothesis, we add the relative net inflows as an explanatory variable and find its coefficient significantly negative at a $99 \%$ confidence level (Table 3, Column H1). We conclude that the flows have an impact on the bond market, as expected. The coefficient of 0.113 gives the order of magnitude of this effect: an inflow amounting to $1 \%$ of the funds' assets reduces the yield to maturity by about $11 \mathrm{bps}$. To gauge the impact in euros, we have to use the FBFs' average net assets over the period, which is $€ 530 \mathrm{bn}$. Hence a $1 \%$ relative inflow is roughly $€ 5 \mathrm{bn}$. The size of the coefficient means that each billion of euros flowing into the FBF causes the yield to fall by about $2 \mathrm{bp}$. We have tried non-linear specifications such as (i) different thresholds of relative flows at $0.5 \%$ or $1 \%$; (ii) the quadratic inflows multiplied by 1 or $(-1)$ according to their sign, but these terms were not found significant.

The effect of net inflows on yields can be merely interpreted as a "demand effect" in the sense that more inflows (outflows) mean more quantities bought (sold) by funds, which exert a direct upward (downward) pressure on prices. This straight effect is not specific to funds, as investors that put money into the FBFs (or withdraw it) may trigger the same effect if they bought (or sold) the same quantities of bonds directly. However, the presence of funds in the bond market may amplify this direct price effect in two ways: (i) funds are generally bigger than individual investors therefore their buying/selling securities is likely to weight more on the market than individuals who do not trade the same securities at the same time. (ii) A signal effect may be as well at play, as funds' transactions release some information to the market. Indeed, bond funds behave quite differently from the other major buyers such as insurance companies or pension funds. The latter often follow a buy-and-hold-to-maturity strategy, buying bonds at the issuance and keeping them until maturity; in this case, bonds never change hands, which explains their low liquidity in the secondary market. Bond mutual funds are atypical in this landscape, since they may pursue a more active management strategy. At least some of them perform a number of transactions in order to benefit from the market trends. According to Anand et al. (2017), the funds that tend to supply liquidity to the market, i.e. increase their bond holdings concomitantly with dealers' inventories, get a better performance on average, measured by the alpha of the fund's return. In this context, those funds are likely to be regarded as informed agents, and their transactions may be seen as revealing information. This information channel is all the more important as there are few transactions in this market. Consequently, when there are unexpected inflows (outflows) to the funds, and bond funds are compelled to buy (sell) bonds, these transactions may release signals of buying (selling) and bring in their wake other players in the market. 
Table 3. Fixed effects regressions, corporate bond yield at the bond-level as dependent variable

\begin{tabular}{|c|c|c|c|c|c|c|c|}
\hline$\cdot$ & Benchmark & $(\mathrm{H} 1)$ & $(\mathrm{H} 2)$ & $(\mathrm{H} 3)$ & $\left(\mathrm{H} 3^{\prime}\right)$ & $(\mathrm{H} 4)$ & (H5) \\
\hline \multirow[t]{2}{*}{ Long rate } & $0.5957^{\star \star \star}$ & $0.5652^{* \star \star *}$ & $0.5547^{\star \star \star}$ & $0.5594^{* \star *}$ & $0.5574^{\star \star \star}$ & $0.5663^{\star * *}$ & $0.5670^{\star * *}$ \\
\hline & [0.0000] & {$[0.0000]$} & {$[0.0000]$} & {$[0.0000]$} & [0.0000] & [0.0000] & [0.0000] \\
\hline \multirow[t]{2}{*}{ Short rate } & $0.6309^{* * *}$ & $0.6475^{\star \star \star}$ & $0.6542^{\star \star \star}$ & $0.6495^{\star \star \star}$ & $0.6499^{\star \star \star *}$ & $0.6293^{\star * *}$ & $0.6354^{* * *}$ \\
\hline & [0.0000] & [0.0000] & {$[0.0000]$} & {$[0.0000]$} & [0.0000] & {$[0.0000]$} & [0.0000] \\
\hline \multirow[t]{2}{*}{ Vstoxx } & $0.0216^{\star \star \star}$ & $0.0181^{\star \star *}$ & $0.0168^{\star \star *}$ & $0.0167^{\star \star \star}$ & $0.0166^{\star \star \star}$ & $0.0176^{\star \star *}$ & $0.0135^{\star \star}$ \\
\hline & [0.0001] & [0.0012] & [0.0023] & {$[0.0017]$} & [0.0018] & [0.0010] & [0.0377] \\
\hline \multirow[t]{2}{*}{ VIX } & $0.0148^{\star * *}$ & $0.0135^{\star * \star}$ & $0.0143^{\star * *}$ & $0.0148^{* * *}$ & $0.0148^{* \star *}$ & $0.0137^{\star * *}$ & $0.0136^{\star * *}$ \\
\hline & [0.0054] & [0.0098] & {$[0.0055]$} & [0.0039] & [0.0037] & [0.0066] & [0.0068] \\
\hline \multirow[t]{2}{*}{ Residual maturity } & $0.0098^{\star \star \star}$ & $0.0106^{\star \star \star}$ & $0.0108^{\star \star *}$ & $0.0101^{\star \star \star *}$ & $0.0101^{\star \star \star *}$ & $0.0101^{\star \star \star *}$ & $0.0101^{\star \star \star *}$ \\
\hline & {$[0.0040]$} & {$[0.0020]$} & {$[0.0017]$} & {$[0.0027]$} & {$[0.0025]$} & [0.0024] & {$[0.0026]$} \\
\hline \multirow[t]{2}{*}{ Proba of default } & $0.2363^{\star \star \star}$ & $0.2358^{\star \star \star}$ & $0.2349^{\star \star *}$ & $0.2357^{\star \star \star}$ & $0.2365^{\star \star \star}$ & $0.2359^{\star \star \star}$ & $0.2362^{\star \star *}$ \\
\hline & [0.0000] & [0.0000] & {$[0.0000]$} & {$[0.0000]$} & {$[0.0000]$} & [0.0000] & [0.0000] \\
\hline \multirow[t]{2}{*}{ Liquidity(-1) } & $0.6308^{* * *}$ & $0.6321^{* * *}$ & $0.6323^{\star * *}$ & $0.6450^{\star * *}$ & $0.6457^{\star \star \star}$ & $0.5921^{* * *}$ & $0.5903^{* * *}$ \\
\hline & [0.0000] & [0.0000] & {$[0.0000]$} & {$[0.0000]$} & [0.0000] & [0.0000] & [0.0000] \\
\hline \multirow[t]{2}{*}{ Share of funds $(-1)$} & & & & -1.7155 & $-2.1874^{\star}$ & $-2.2225^{*}$ & $-3.0169^{\star \star}$ \\
\hline & & & & [0.1390] & [0.0582] & [0.0548] & [0.0245] \\
\hline CSPP & Yes *** & Yes ${ }^{* \star \star}$ & 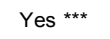 & Yes ${ }^{* \star \star}$ & Yes ${ }^{* \star \star}$ & Yes *** & Yes ${ }^{* \star \star}$ \\
\hline \multirow[t]{2}{*}{ Flows } & & $-0.1131^{\star \star \star}$ & $-0.0680^{\star *}$ & -0.0250 & $-0.0997^{* \star *}$ & $-0.1063^{* \star \star}$ & $-0.1087^{\star \star \star}$ \\
\hline & & {$[0.0000]$} & {$[0.0249]$} & [0.4539] & [0.0039] & [0.0024] & [0.0019] \\
\hline \multirow[t]{2}{*}{ Outflows } & & & $-0.1005^{\star \star}$ & $-0.1027^{\star \star}$ & 0.0690 & $0.2629^{\star \star}$ & $0.2508^{\star \star}$ \\
\hline & & & {$[0.0324]$} & [0.0268] & [0.2588] & [0.0169] & [0.0207] \\
\hline \multirow[t]{2}{*}{ Flows ${ }^{*}$ Share of funds $(-1)$} & & & & $-0.4112^{\star \star}$ & $0.3163^{*}$ & $0.3250^{*}$ & $0.3528^{\star \star}$ \\
\hline & & & & [0.0113] & {$[0.0711]$} & [0.0604] & [0.0395] \\
\hline \multirow[t]{2}{*}{ Outflows ${ }^{*}$ Share of funds $(-1)$} & & & & & $-1.7020^{\star \star \star}$ & $-1.7791^{\star \star \star}$ & $-1.6612^{\star \star \star}$ \\
\hline & & & & & [0.0005] & [0.0002] & [0.0001] \\
\hline \multirow[t]{2}{*}{ Outflows*Liquidity(-1) } & & & & & & $-0.2440^{\star \star}$ & $-0.2439^{\star *}$ \\
\hline & & & & & & [0.0293] & [0.0292] \\
\hline \multirow[t]{2}{*}{ Vstoxx ${ }^{*}$ Share of funds $(-1)$} & & & & & & & 3.9684 \\
\hline & & & & & & & [0.2539] \\
\hline R-squared & 0.5813 & 0.5844 & 0.5847 & 0.5819 & 0.5827 & 0.5844 & 0.5847 \\
\hline Observations & 13,518 & 13,518 & 13,518 & 13,353 & 13,353 & 13,353 & 13,353 \\
\hline Number of ISIN & 390 & 390 & 390 & 385 & 385 & 385 & 385 \\
\hline
\end{tabular}

Note: Estimation of Models (1) to (5). Long rate: French 10-y sovereign rate; short rate: 3-month Euribor; Prob of default: probability of default of each bond extracted from Bloomberg; Liquidity: bid-ask spread; CSSP are the lags ot the CSPP variable shown in Table 2; Flows are the relative flows to funds calculated by Equation (2); "Flows*share of funds" is the interactive variable between flows and the share of funds in each bond market defined in Equation (2); "Outflows*share of funds" is the negative part of the previous variable. "Outflows*Liq" is the interactive variable between the redemptions (negative part of flows) and bond liquidity (bid-ask-spread). "Vstoxx*share of funds" is the interactive variable between the Vstoxx and the share of funds in each bond market. Robust $\mathrm{p}$-values in brackets, *** $\mathrm{p}<0.01, * * \mathrm{p}<0.05, * \mathrm{p}<0.1$

\subsection{The asymmetric effect of redemptions}

To assess the second hypothesis, we include the negative part of the flows into the regression. The coefficient of the outflows coefficient is found significant and negative, while that of the positive inflows are no longer significant (Table 3, Column H2). This means that the former results that showed the effect of flows were only driven by their negative part. As outflows are negative, the minus sign means that they exert an upward pressure on yields, as expected. This effect is added on the top of the standard effect of inflows/outflows captured by the variable "Flows". Coefficients show a rather strong asymmetry: $1 \%$ relative inflows reduces the yield-to-maturity by 7 bps although not significantly, whereas a $1 \%$ outflows significantly raises it by 17 bps $(=-0.0680-0.1005)$.

This asymmetric effect raises concerns about financial stability, especially if the flows-to-performance relation is concave like Goldstein et al. (2017) have shown for bonds funds in the US. This means that redemptions following bad performance are greater than the inflows resulting from good results, hence 
the bad performance and redemptions may fuel each other in a vicious circle. In this case, the bond market can be affected badly in times of crises. The rationale for this asymmetric effect is likely to stem from the low liquidity of the corporate bond secondary market. Indeed, when facing redemptions, funds have to sell a part of their securities on the secondary market, which is illiquid, whereas they do not have to turn to this market when receiving inflows. In this case, they often purchase newly issued securities directly on the primary market, which is observed by our data. A remaining question is to know why funds do not use their cash instead of selling securities in times of redemptions. Indeed, some studies suggest that funds with less liquid assets keep higher levels of cash in order to be able to face investors' redemptions without transacting in the underlying portfolio assets. Chernenko and Sunderam (2016) argue that funds engage in substantial liquidity management to accommodate in/outflows, although funds' cash holdings are not sufficient to mitigate price impact on the assets. Choi and Shin (2016) reach a similar conclusion that price pressure on bonds is more pronounced for those bonds that are held by low-cash funds. Actually, low-cash funds (less than $5 \%$ of their assets) represent a large proportion of the U.S. corporate bond funds. In the case of the French bond and mixed funds, the average cash holdings are about $5 \%$ and $3 \%$ accordingly, but these average figures may hide significant cross-sectional heterogeneity.

\subsection{Detention by funds and the bond yield response to redemptions}

We now test for a differentiated impact of the funds according to their holdings in the market, by adding an interactive variable equal to the relative flows multiplied by the share of each bond market held by funds into the regression (Table 3, Column H3 and H3'). We find this variable significant. In other words, the in(out)flows exert stronger pressures on the market price (and the yield) of the bonds that are more owned by the funds. Given the asymmetric effect found in the previous regression, we add an interactive variable taking into account the market share of the funds combined with the outflows. Results strongly confirm the asymmetric effect. The bonds that are more owned by the funds have their yields increased more by redemptions than inflows.

This result suggests that high concentration of funds in a security has disturbing effects on its price and make it more vulnerable to shocks. This finding interacts with the idea of stock price fragility proposed by Greenwood and Thesmar (2011) who claim that stocks with concentrated ownership experience higher price volatility.

\subsection{Liquidity premia during redemptions periods and response to financial stress}

Turning to a possible impact of redemptions on the liquidity premia, we introduce an interactive variable between liquidity and the withdrawals from funds in addition to the control variable of liquidity. The interactive variable is found significant at a $95 \%$ level (Table 3, Column H4). As negative flows $\phi_{t}$ are negative and Liquidity measures illiquidity, this negative sign means that redemptions tend to increase more the yields of the less liquid bonds. This result may stem from two possible effects: (i) a quantity effect: illiquid bonds being sold more in times of redemptions than liquid ones, or (ii) a price effect : all the bonds are sold across the board, but the response of price is sharper for less liquid bonds.

To better understand which effect is at stake, we extract the set of bonds sold during redemption periods from our database. For these bonds, we calculate the share of the FBFs' holdings sold during redemption periods and split it into quintiles. The first quintile includes the bonds that are the most sold in percentage of funds' holdings during these periods; it includes a number of bonds that are entirely liquidated, i.e. $100 \%$ of the holdings are sold during such periods. For each quintile, we calculate the mean liquidity, i.e. bid-ask spread, and residual maturity, as well as one standard deviation around the mean (Figure 6). On average, the bonds that are the most sold during redemption periods are slightly more illiquid than the others, although standard deviations within the quintiles of sold bonds are too 
large to conclude to any significant difference across the quintiles. We also see that funds sell bonds with longer residual maturity on average in times of redemptions; however, here again, standard deviations are too large to conclude.

Figure 6. Liquidity and residual maturity of the bonds sold during the redemption periods

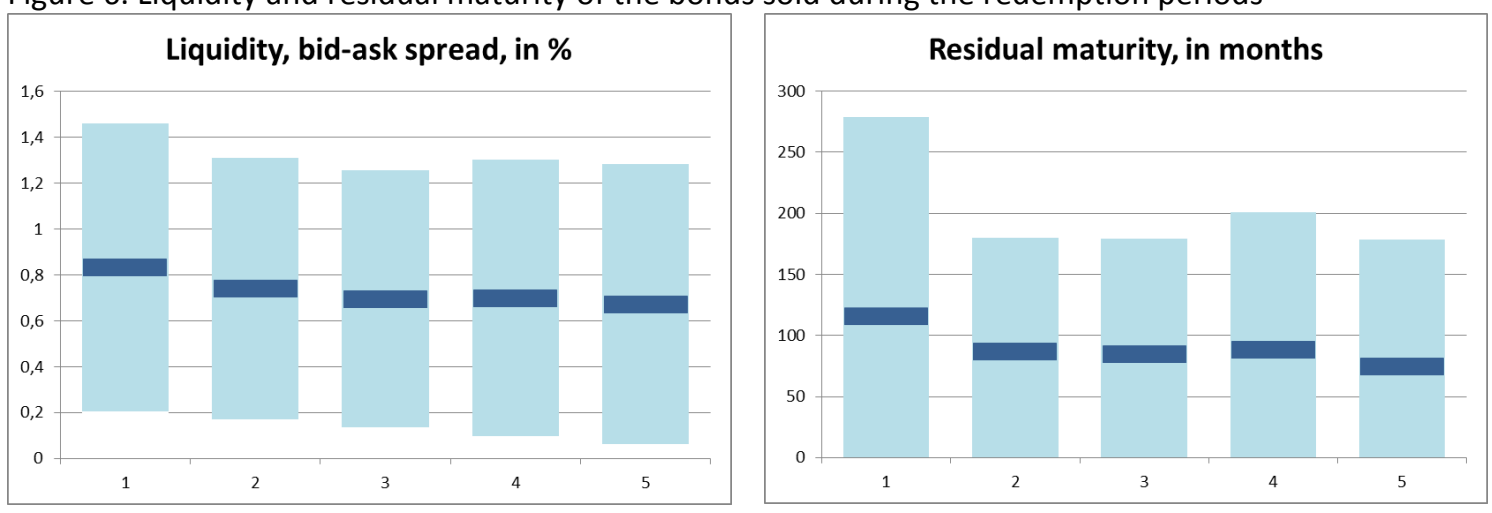

Note: The blue lines correspond to mean liquidity and residual maturity of sold bonds per quintile, and the bars correspond to 1 standard deviation from the mean. Each column corresponds to quintiles where the 1st quintile stands for the bonds that are the most sold during redemption periods in percentage of funds' holdings. Maturity of perpetual bonds is set to 50 years in order to avoid dropping observations.

On the whole, our data show that funds tend to sell corporate bonds regardless of their liquidity or maturity in times of redemptions. This result complements other studies who focused on large asset classes instead of individual securities within one class. Chernenko and Sunderam (2016), Jiang et al. (2018), Choi and Shin (2017) found that outflows hit all asset classes but particularly the most liquid ones (cash-like securities, government bonds, etc.).

Coming back to our regression results, we conclude at this stage that liquidity premia of less liquid bonds increase more in times of redemptions because of their sharper response to sales. However, robustness tests in Section 5 will show that this result is not robust.

Regarding our last hypothesis, we test if funds' ownership affects bond yields in periods of stress (Table 3, Column H5), either by amplifying or mitigating the price effect on bonds during financial turmoil. The results are not significant at this stage.

\section{Robustness tests}

We now proceed to several types of robustness checks. First, we correct standard deviations of coefficients of the residual dependency and introduce time effects. Second, we use a different econometric specification through dynamic panel data estimations. Then, we adopt alternative definitions of our variable of interest in the regressions, namely the relative flows in the FBF. Finally, we address some possible endogeneity issues.

\subsection{Correction for dependence of residuals}

As a robustness test, we address the issue of cross-sectional dependence in the disturbances that may lead to an undervaluation of the standard errors of coefficients. This problem may arise as a number of our explanatory variables are macroeconomic and not bond-specific (Moulton, 1990). To do so, we use the Driscoll and Kraay (1998) procedure for estimating covariance matrix in cross-sectional dependent panel data. Consequently, all the standard errors of coefficients (and p-values) are corrected upwards. The key variables of the first three models remain significant at the $95 \%$ level, despite a slight increase in their p-values, confirming our previous results. However, the coefficient on the interactive liquidity variable in Model (4) is not significant anymore. As all coefficients remain exactly the same as in Table 3, 
only their p-values change, we do not report these complete results. Instead, we provide results after adding time fixed effects.

As a further robustness test, we include time fixed effects in these regressions with standard errors corrected for cross-sectional dependence (Table 4). As expected, macroeconomic variables turn less significant when time dummies are added; this is also true for bond-specific residual maturity, which is correlated to the passage of time. The results confirm our previous findings for the first three hypotheses as coefficients of key variables remain significant in Models (1) to (3). However, the interactive liquidity variable is not significant anymore in Model (4). Hence the hypothesis that liquidity premia are affected by redemptions is not confirmed. Lastly, funds ownership of bonds still does not have any significant impact on the resilience of bond yields to stress in Model 5.

Table 4. Fixed effects regressions, corporate bond yield at the bond-level as dependent variable, time effects and Driscoll and Kraay correction of residual dependency

\begin{tabular}{|c|c|c|c|c|c|c|c|}
\hline & Benchmark & (H1) & $(\mathrm{H} 2)$ & $(\mathrm{H} 3)$ & $\left(\mathrm{H}^{\prime}\right)$ & (H4) & (H5) \\
\hline \multirow[t]{2}{*}{ Long rate } & $0.5231^{*}$ & $0.5836^{*}$ & 0.3252 & 0.5761 & 0.5909 & $0.5975^{\star}$ & 0.6326 \\
\hline & [0.0604] & {$[0.0787]$} & [0.3219] & [0.1094] & [0.1040] & {$[0.0907]$} & [0.1053] \\
\hline \multirow[t]{2}{*}{ Short rate } & $1.5147^{\text {***}}$ & $1.3918^{\star * *}$ & $1.3410^{* * *}$ & $1.3151^{* * *}$ & $1.2853^{\star * *}$ & $1.2537^{* * *}$ & $1.2202^{* \star *}$ \\
\hline & {$[0.0000]$} & {$[0.0000]$} & {$[0.0000]$} & {$[0.0000]$} & {$[0.0000]$} & {$[0.0000]$} & {$[0.0000]$} \\
\hline \multirow[t]{2}{*}{ Vstoxx } & 0.0045 & -0.0028 & -0.0045 & 0.0056 & 0.0055 & 0.0093 & 0.0067 \\
\hline & [0.7123] & {$[0.7906]$} & {$[0.7207]$} & [0.6540] & [0.6630] & [0.4083] & {$[0.4700]$} \\
\hline \multirow[t]{2}{*}{ VIX } & $0.0047^{\star *}$ & $0.0107^{\star * *}$ & $0.0222^{\star * *}$ & $0.0096^{* * *}$ & $0.0105^{\star \star \star}$ & 0.0058 & 0.0056 \\
\hline & {$[0.0485]$} & {$[0.0000]$} & [0.0000] & {$[0.0000]$} & {$[0.0000]$} & [0.2054] & {$[0.2086]$} \\
\hline \multirow[t]{2}{*}{ Residual maturity } & 0.0047 & 0.0047 & 0.0047 & 0.0035 & 0.0036 & 0.0042 & 0.0041 \\
\hline & [0.5586] & [0.5586] & [0.5586] & [0.6906] & [0.6800] & [0.6282] & {$[0.6460]$} \\
\hline \multirow[t]{2}{*}{ Proba of default } & $0.2118^{\star \star \star}$ & $0.2118^{\star \star \star}$ & $0.2118^{\star \star *}$ & $0.2129^{\star \star \star}$ & $0.2135^{\star \star \star}$ & $0.2124^{\star \star \star}$ & $0.2125^{\star \star \star}$ \\
\hline & [0.0000] & {$[0.0000]$} & {$[0.0000]$} & [0.0000] & {$[0.0000]$} & {$[0.0000]$} & {$[0.0000]$} \\
\hline \multirow{2}{*}{ Liquidity(-1) } & $0.5727^{* * *}$ & $0.5727^{\star \star *}$ & $0.5727^{* * *}$ & $0.5845^{\star * *}$ & $0.5854^{* * *}$ & $0.5220^{\star \star *}$ & $0.5196^{\text {*** }}$ \\
\hline & {$[0.0000]$} & [0.0000] & {$[0.0000]$} & {$[0.0000]$} & [0.0000] & {$[0.0000]$} & {$[0.0000]$} \\
\hline \multirow[t]{2}{*}{ Share of funds(-1) } & & & & $-1.7510^{\text {*** }}$ & $-2.2225^{\star \star *}$ & $-2.2587^{* * *}$ & $-3.1604^{* *}$ \\
\hline & & & & {$[0.0007]$} & [0.0003] & [0.0002] & [0.0408] \\
\hline CSPP & Yes *** & Yes *** & Yes *** & Yes *** & Yes *** & Yes *** & Yes *** \\
\hline \multirow[t]{2}{*}{ Flows } & & $-0.0847^{\star \star \star}$ & 0.0250 & $0.3112^{\star * *}$ & $0.2418^{\star \star *}$ & $0.2187^{\star \star *}$ & $0.2194^{\star \star *}$ \\
\hline & & {$[0.0000]$} & {$[0.8675]$} & {$[0.0005]$} & {$[0.0002]$} & {$[0.0026]$} & {$[0.0038]$} \\
\hline \multirow[t]{2}{*}{ Outflows } & & & $-0.3552^{\star *}$ & $-0.4452^{\star \star \star}$ & $-0.2849^{\star \star \star}$ & -0.0003 & -0.0150 \\
\hline & & & [0.0145] & {$[0.0000]$} & [0.0000] & [0.9989] & {$[0.9470]$} \\
\hline \multirow[t]{2}{*}{ Flows ${ }^{*}$ Share of funds $(-1)$} & & & & $-0.3564^{*}$ & $0.3717^{*}$ & $0.3782^{*}$ & 0.4095 \\
\hline & & & & {$[0.0516]$} & [0.0804] & {$[0.0770]$} & {$[0.1037]$} \\
\hline \multirow[t]{2}{*}{ Outflows ${ }^{*}$ Share of funds $(-1)$} & & & & & $-1.7027^{\star \star \star}$ & $-1.7765^{\star * *}$ & $-1.6414^{\star * *}$ \\
\hline & & & & & {$[0.0053]$} & {$[0.0042]$} & {$[0.0004]$} \\
\hline \multirow[t]{2}{*}{ Outflows*Liquidity(-1) } & & & & & & -0.2850 & -0.2848 \\
\hline & & & & & & {$[0.1421]$} & {$[0.1418]$} \\
\hline \multirow[t]{2}{*}{ Vstoxx ${ }^{*}$ Share of funds $(-1)$} & & & & & & & 4.5024 \\
\hline & & & & & & & {$[0.4015]$} \\
\hline Time dummies & yes & yes & yes & yes & yes & yes & yes \\
\hline Observations & 13,518 & 13,518 & 13,518 & 13,353 & 13,353 & 13,353 & 13,353 \\
\hline Number of ISIN & 390 & 390 & 390 & 385 & 385 & 385 & 385 \\
\hline
\end{tabular}

Note: Estimation of Models (1) to (5) with fixed effects. Long rate: French 10-y sovereign rate; short rate: 3-month Euribor; Prob of default: probability of default of each bond extracted from Bloomberg; Liquidity: bid-ask spread; CSSP are the lags ot the CSPP variable shown in Table 2; Flows are the relative flows to funds calculated by Equation (2); "Flows*share of funds" is the interactive variable between flows and the share of funds in each bond market defined in Equation (2); "Outflows*share of funds" is the negative part of the previous variable. "Outflows * Liq" is the interactive variable between the redemptions (negative part of flows) and bond liquidity (bid-ask-spread). "Vstoxx*share of funds" is the interactive variable between the Vstoxx and the share of funds in each bond market. $p$-values are corrected by the Driscoll and Kraay procedure in brackets, $* * * p<0.01, * * p<0.05, * p<0.1$ 


\subsection{Dynamic specification}

As another robustness test, we run the same econometric models using dynamic panel data estimations. This specification serves two purposes: to avoid endogeneity problems and to correct for potential autoregressive error since bond yields are likely to be autoregressive. Given that the sample includes more panels than time periods and is subject to heteroscedasticity, we first use the ArenalloBond estimations. However, the residuals of these estimations are autoregressive at the first and second orders, which invalidates the approach. We hence retain the Arellano-Bover/Blundell-Bond procedure. In this latter specification, the autocorrelation pattern of the residuals shows no evidence of misspecification when including one lag on the dependent variable. All coefficients are significant with the expected signs.

The estimations confirm our previous findings (Table 5). First, the flows entering the funds exert a significant downward pressure on the yields at a 99\% confidence level, which comforts the former results (Column $\mathrm{H} 1$ ). Second, the effect is strongly asymmetric, as redemptions raise yields to maturity significantly at $99 \%$ level of confidence, whereas inflows are no longer significant (Column H2). Third, redemptions exert a stronger effect on the bonds that are more owned by the FBFs, as shown by the interactive variable of the flows multiplied by the share of funds in the bond market which is significant (Column H3'), although the effect is not significant in case of inflows (Column H3). The large ownership of bonds by funds has then an impact on the bond market only in times of outflows. In other words, the more the funds hold of a bond, the larger the increase in its yield in times of withdrawals. This situation seems rather unfavorable as it is not compensated by the benefit of lower rates in times of inflows.

Fourth, in this specification, the interactive variable between redemptions and liquidity turns significant (Column H4). This effect is on the top of the standard liquidity premium that is captured by the liquidity proxy in the control variables. The negative sign indicates that illiquid bonds are more affected by redemptions than others, as with the previous results in Section 4.5.

Lastly, the equity market volatility, measured both by the Vstoxx and the VIX, raises the bond yields across the board as shown in the control variables as in the former regressions. On the top of this effect, we now find significant differences across the bonds that are more or less detained by funds in this specification (Column H5). The more bonds are detained by funds, the more their yields tend to rise with the volatility of the equity market. This result suggests that funds may want to reallocate their portfolio either to raise cash or to reduce exposures to riskier bonds during a stress period. This finding may be related to the IMF (2015) study that indicates a positive relationship between ownership concentration of U.S. corporate bonds and the change in their credit spreads between 2008:Q2 and 2008:Q4. 
Table 5: Dynamic panel data regressions, corporate bond yield as dependent variable

\begin{tabular}{|c|c|c|c|c|c|c|c|}
\hline & Benchmark & $(\mathrm{H} 1)$ & $(\mathrm{H} 2)$ & $(\mathrm{H} 3)$ & $\left(\mathrm{H}^{\prime}\right)$ & $(\mathrm{H} 4)$ & (H5) \\
\hline \multirow[t]{2}{*}{ yield $(-1)$} & $0.8707^{\star \star *}$ & $0.8685^{\star \star *}$ & $0.8679^{\star \star *}$ & $0.8701^{* * *}$ & $0.8696^{\star * *}$ & $0.8674^{\star \star *}$ & $0.8656^{\star * *}$ \\
\hline & [0.0000] & [0.0000] & {$[0.0000]$} & [0.0000] & [0.0000] & [0.0000] & [0.0000] \\
\hline \multirow[t]{2}{*}{$\Delta$ Long rate } & $0.2914^{\star * *}$ & $0.2759^{\star \star *}$ & $0.2559^{\star * *}$ & $0.2515^{\star \star \star}$ & $0.2501^{* * *}$ & $0.2555^{\star \star *}$ & $0.2480^{\star * *}$ \\
\hline & [0.0000] & [0.0000] & {$[0.0000]$} & [0.0000] & [0.0000] & [0.0000] & [0.0000] \\
\hline \multirow[t]{2}{*}{$\Delta$ Short rate } & $0.3654^{* * *}$ & 0.1646 & 0.1712 & $0.2443^{*}$ & $0.2469^{*}$ & 0.1720 & 0.1768 \\
\hline & [0.0025] & [0.1604] & [0.1389] & [0.0742] & {$[0.0714]$} & [0.1969] & [0.1954] \\
\hline \multirow[t]{2}{*}{ Vstoxx } & 0.0043 & 0.0026 & 0.0010 & 0.0024 & 0.0027 & 0.0035 & -0.0015 \\
\hline & [0.1462] & [0.4018] & [0.7628] & [0.4924] & [0.4375] & [0.3217] & [0.6629] \\
\hline \multirow[t]{2}{*}{$\Delta$ Vstoxx } & $0.0122^{* * *}$ & $0.0122^{* * *}$ & $0.0126^{* * *}$ & $0.0119^{* * *}$ & $0.0117^{* * *}$ & $0.0119^{* * *}$ & $0.0107^{* * *}$ \\
\hline & [0.0000] & [0.0000] & [0.0000] & [0.0000] & [0.0000] & [0.0000] & [0.0000] \\
\hline \multirow[t]{2}{*}{ VIX } & $0.0105^{\star \star \star}$ & $0.0116^{\star \star *}$ & $0.0118^{\star * *}$ & $0.0121^{* \star *}$ & $0.0121^{* \star *}$ & $0.0109^{* * *}$ & $0.0110^{* * *}$ \\
\hline & [0.0001] & {$[0.0000]$} & {$[0.0000]$} & [0.0000] & {$[0.0000]$} & [0.0001] & [0.0001] \\
\hline \multirow[t]{2}{*}{ Liquidity } & $0.1521^{\star * *}$ & $0.1669^{\star \star *}$ & $0.1721^{\star \star *}$ & $0.1682^{\star \star}$ & $0.1701^{* \star}$ & $0.1373^{\star \star}$ & $0.1472^{\star *}$ \\
\hline & [0.0098] & [0.0065] & [0.0053] & [0.0116] & [0.0110] & [0.0266] & [0.0167] \\
\hline \multirow[t]{2}{*}{$\Delta$ Liquidity } & $0.1010^{*}$ & 0.0890 & 0.0846 & 0.0868 & 0.0852 & $0.1194^{* *}$ & $0.1122^{* *}$ \\
\hline & [0.0753] & {$[0.1134]$} & [0.1295] & [0.1208] & [0.1257] & [0.0296] & [0.0379] \\
\hline \multirow[t]{2}{*}{$\Delta$ Probability of default } & $0.1242^{\star \star \star}$ & $0.1108^{* \star *}$ & $0.1115^{\star \star \star}$ & $0.1117^{\star \star \star}$ & $0.1102^{\star \star *}$ & $0.1045^{\star \star \star}$ & $0.0998^{* * *}$ \\
\hline & [0.0018] & {$[0.0041]$} & {$[0.0038]$} & [0.0035] & [0.0037] & {$[0.0051]$} & {$[0.0071]$} \\
\hline \multirow[t]{2}{*}{ Share_funds $(-1)$} & & & & -0.4534 & -0.5278 & -0.2555 & -0.8534 \\
\hline & & & & {$[0.4635]$} & [0.3881] & [0.6671] & {$[0.1714]$} \\
\hline CSPP & $\mathrm{YES}^{* * *}$ & YES*** & $\mathrm{YES}^{* * *}$ & YES $* * *$ & $\mathrm{YES}^{* * *}$ & $\mathrm{YES}^{* * *}$ & YES*** \\
\hline \multirow[t]{2}{*}{ Flow s } & & $-0.0623^{* * *}$ & -0.0105 & -0.0034 & -0.0293 & -0.0284 & -0.0091 \\
\hline & & {$[0.0000]$} & {$[0.5587]$} & [0.8512] & {$[0.1635]$} & {$[0.1630]$} & {$[0.6246]$} \\
\hline \multirow[t]{2}{*}{ Outflows } & & & $-0.1152^{\star \star *}$ & $-0.1147^{\star \star *}$ & -0.0546 & 0.0776 & 0.0224 \\
\hline & & & {$[0.0010]$} & {$[0.0010]$} & [0.1945] & [0.2066] & [0.6948] \\
\hline \multirow[t]{2}{*}{ Flow $s^{*}$ Share of funds $(-1)$} & & & & -0.0362 & $0.2341^{\star *}$ & $0.2138^{*}$ & 0.1058 \\
\hline & & & & [0.4919] & {$[0.0440]$} & {$[0.0521]$} & {$[0.2635]$} \\
\hline \multirow[t]{2}{*}{ Outflow $s^{*}$ Share of funds $(-1)$} & & & & & $-0.6213^{* *}$ & $-0.5787^{*}$ & -0.2322 \\
\hline & & & & & [0.0496] & {$[0.0586]$} & [0.3683] \\
\hline \multirow[t]{2}{*}{ Outflow s*Liquidity(-1) } & & & & & & $-0.1829^{* * *}$ & $-0.1665^{\star * *}$ \\
\hline & & & & & & [0.0042] & {$[0.0083]$} \\
\hline \multirow[t]{2}{*}{ Vstoxx ${ }^{*}$ Share of funds $(-1)$} & & & & & & & $6.8118^{* *}$ \\
\hline & & & & & & & {$[0.0217]$} \\
\hline Observations & 13,468 & 13,468 & 13,468 & 13,311 & 13,311 & 13,311 & 13,311 \\
\hline Number of ISIN & 390 & 390 & 390 & 385 & 385 & 385 & 385 \\
\hline
\end{tabular}

Note: Estimation of Models (1) to (5) with the Arellano-Bover/Blundell-Bond procedure. Residuals are found not autocorrelated at an order greater than one. Long rate: French 10-y sovereign rate; short rate: 3-month Euribor; Prob of default: probability of default of each bond extracted from Bloomberg; Liquidity: bid-ask spread; Flows are the relative flows to funds calculated by Equation (2); "Flows* share of funds" is the interactive variable between flows and the share of funds in each bond market defined in Equation (2); "Outflows*share of funds" is the negative part of the previous variable. "Outflows *Liq" is the interactive variable between the redemptions (negative part of flows) and bond liquidity (bid-ask-spread). "Vstoxx*share of funds" is the interactive variable between the Vstoxx and the share of funds in each bond market. Robust $p$-values in brackets, $* * * p<0.01, * * p<0.05, *$ $\mathrm{p}<0.1$

\subsection{Alternative definitions of relative flows}

As the relative flows are the key variable to our analysis, we test alternative specifications of this ratio in our regressions. Until now, we have defined it as the total flows in the FBF divided by the total net assets under management, as stated in Equation (2), both flows to bond and mixed funds being aggregated in the definition. This definition could be criticized on the grounds that flows to bond and mixed funds are indistinctly aggregated, although their assets are quite different. Indeed, flows pouring into bond funds are allocated mainly in bonds, whereas only a small fraction of flows entering into the mixed funds are invested into bonds. 
We hence propose two alternative measures of the relative flows to address this issue. We extract the bond holdings of both mixed and bond funds, then compare them to the total funds' net assets under management for each category of funds. These four time-series have already been depicted in Figure 1. We then calculate the shares of bonds in the total assets held by each category of funds:

$$
\rho_{t k}=\frac{B_{t-1}^{k}}{A_{t-1}^{k}}
$$

Where $\rho_{t}^{k}$ denotes the share of bonds in the total net assets of type $k$ funds for $k=B$, bonds or $M$ mixed funds, $B_{t}^{k}$; the total amount of bonds detained by type $k$ fund, calculated by aggregating all the bonds in the database by type of funds, and $A_{t}^{k}$, the assets under management of type $k$ fundsThese shares are rather stable over the period, around $50 \%$ for the bond funds and $20 \%$ for the mixed funds (Figure 7 ).

Figure 7. Share of bonds in the total net assets of mixed and bond funds

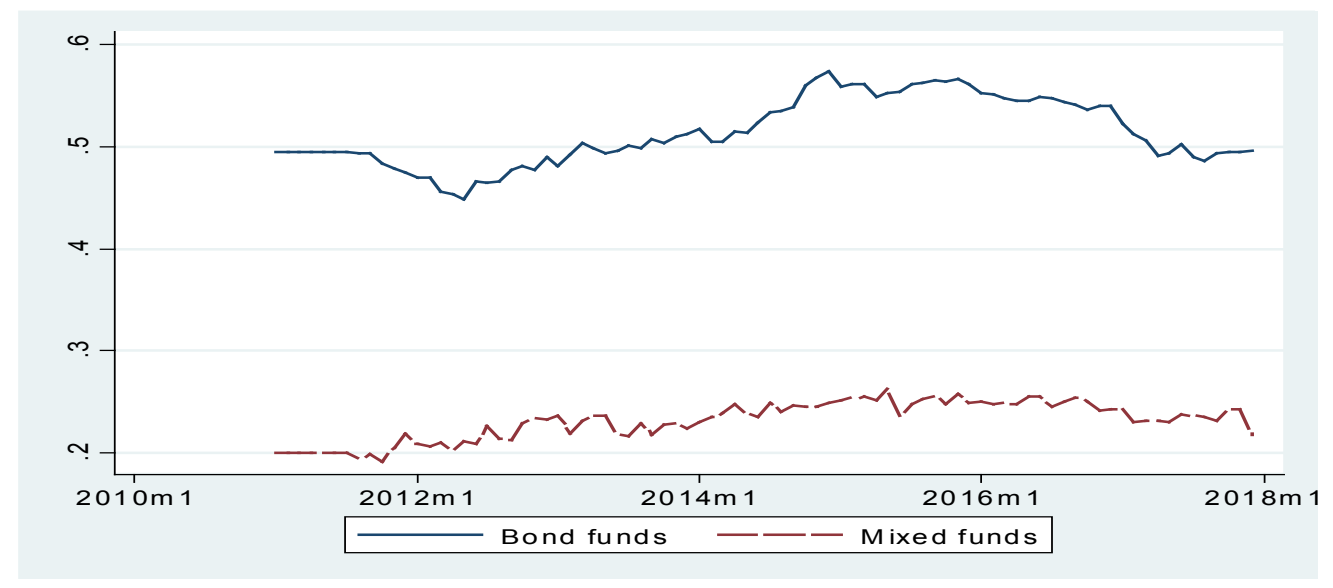

We can now proxy the amount of flows likely to be invested into bonds as the sum of the observed flows at time $t$ weighted by these shares at time $t-1: \rho_{t-1}^{B} F_{t}^{B}+\rho_{t-1}^{M} F_{t}^{M}$, where $F_{t}^{k}$ Is the net flows in type $k$ fund. This provides us with a first alternative measure of relative funds $\varphi^{\prime}{ }_{t}$, which is equal to the amount of flows likely to be invested into bonds divided by the total net assets under management of both fund types (and taken as a percentage).

$\varphi^{\prime}{ }_{t}=100 * \frac{\rho_{t-1}^{B} F_{t}^{B}+\rho_{t-1}^{M} F_{t}^{M}}{A_{t-1}^{B}+A_{t-1}^{M}}$

Another alternative measure of relative flows assigns fixed weights of $50 \%$ for bond funds flows and $20 \%$ for mixed funds. This makes sense as the share of bonds in the total assets of both fund types is quite stable around these values over time.

$\varphi^{\prime \prime}{ }_{t}=100 * \frac{0.5 F_{t}^{B}+0.2 F_{t}^{M}}{A_{t-1}^{B}+A_{t-1}^{M}}$

We then rerun the estimations with these alternative measures of relative flows. Table 6 summarizes all the obtained results. The alternative definitions of net flows do not change the previous results, which are confirmed with approximately the same level of confidence. 
Table 6. Robustness tests with alternative specifications of the relative flows.

\begin{tabular}{|c|c|c|c|c|c|c|c|}
\hline & \multirow[b]{2}{*}{ Tested hypotheses } & \multicolumn{3}{|c|}{ Fixed effects } & \multicolumn{3}{|c|}{ Dynamic Panel } \\
\hline & & $\begin{array}{c}\text { Flows } \\
\text { Total }\end{array}$ & $\begin{array}{c}\text { Flows' } \\
\text { Var weights }\end{array}$ & $\begin{array}{l}\text { Flows " } \\
\text { Fixed weight }\end{array}$ & $\begin{array}{l}\text { Flows } \\
\text { Total }\end{array}$ & $\begin{array}{c}\text { Flows' } \\
\text { Var weights }\end{array}$ & $\begin{array}{c}\text { Flows " } \\
\text { Fixed weight }\end{array}$ \\
\hline $\mathrm{H} 1$ & Relative flows have an impact on YTM & YES*** & YES*** & YES*** & YES*** & YES*** & YES*** \\
\hline $\mathrm{H} 2$ & Asymmetry: greater impact of outflows & YES** & YES** & YES* & YES*** & YES*** & YES*** \\
\hline H3 & Stronger impact of flows for bonds more held by funds & YES** & YES** & YES*** & NO & NO & NO \\
\hline $\mathrm{H}^{\prime}$ & Stronger impact of outflows for bonds more held by funds & YES*** & YES*** & YES*** & YES** & YES*** & YES*** \\
\hline $\mathrm{H} 4$ & Stronger impact of outflows on the less liquid bonds & YES** & YES** & YES* & YES*** & YES*** & YES*** \\
\hline H5 & $\begin{array}{l}\text { Stronger impact of financial stress for the bonds that are } \\
\text { more held by funds }\end{array}$ & NO & NO & NO & YES** & YES** & YES** \\
\hline
\end{tabular}

Note: YES $* * *(* *, *)$ means that the hypotheses are accepted at a $99 \%$; (** 95\%; *90\%) confidence level; NO means that there is no significant evidence. Flows are net flows as a percentage of assets under management (Equation 2); Flows' and Flows" are the average of flows entering the bond and the mixed funds weighted by the share of bonds in the assets under management of the two types of funds; Flows' has a variable weighting (Equation 4); Flows" has a fixed weighting (Equation 5).

\subsection{Other possible endogeneity issues}

Flows are known to be linked to funds past performance (Ippolito, 1992; Sirri and Tufano, 1993). If in turn, past performance is a good predictor for future returns, the equations explaining returns by flows may be subject to endogeneity issues. In our case, this problem is greatly alleviated since our dependent variable is bond yield-to-maturity, not funds return. Moreover, we deal with the French corporate bonds only, whereas the flows into funds are allocated mostly into sovereign and foreign bonds. Hence, the corporate bond yield is not likely to drive investors' decisions to inject/withdraw cash in the funds. Besides, studies have shown that flows do not predict future returns in the case of equity funds; on the contrary, stocks bought by funds have a tendency to have lower returns than the others (Frazzini and Lamont, 2008).

Nevertheless, a way of addressing this issue is to extract the unexpected component in the funds' net flows, or "surprises", $\phi_{t}^{S}$ by following a common approach (see, e.g., Edelen and Warner (2001), Acharya et al. (2014)). The "surprise" net flows are obtained as the residuals of the regression of the flows $\phi_{t}^{S}$ on their lagged values and the lagged performances of funds. Performance is measured as the monthly valorization divided by funds' outstanding assets in the previous month. Two or three lags are retained in the regression. The results show that the unexpected component of flows is very close to the observed flows. Consequently, when we replace the relative flows by their unexpected components and rerun the regressions, the results are very similar; in particular, it does not change the tests on the hypotheses. $^{2}$

\section{Conclusion}

In this paper, we analyze the potential effects exerted by the French bond and mixed mutual funds (FBF) on the corporate bond market, using Bank of France data on their holdings and flows. The question of fund flows and price effect has been studied in the literature but mostly for equity funds. However, given lower liquidity of corporate bonds market and the growing size of asset management industry, the analysis of the effect of fund flows on corporate bond prices is of particular importance for financial stability.

We test for several hypotheses using panel regressions at the bond-level through different estimation methods. First, we find that net fund flows significantly affect bond yields-to-maturity; more specifically, when funds face inflows (outflows), bond yields tend to decrease (increase). Second, we show that this effect is strongly asymmetric as the investors' withdrawals from FBF have more adverse effects in increasing bond yields than inflows have favorable ones in alleviating them. Third, the price effect is

\footnotetext{
2 Results are not reported for the sake of brevity but are available from the authors.
} 
stronger for those bonds that are held by funds to a larger extent. The more a bond is detained by funds, the more its yield is sensitive to redemptions. These results are robust to different specifications as well as alternative definitions of the relative flows entering the funds. Besides, two other results emerge from the dynamic panel estimations, although they are not found robust in the fixed effects regressions. These results suggest that outflows tend to raise liquidity premia above the standard effect of liquidity for less liquid bonds. Moreover, bonds that are the most detained by funds appear more sensitive to financial volatility.

Some policy implications can be drawn from this study. First, due to large holdings of assets by funds, price effects of asset liquidation may not be neutral in illiquid markets such as corporate bonds. Second, the larger the funds' holdings in a certain asset the larger is the price effect, thus particular attention should be paid to the concentration of asset holdings by one institution or one type of institutions. The traditional diversification notion concerns investors' portfolio and is meant to avoid specific risk. We suggest that diversification of holders of a certain asset may be a way forward to avoid significant price effects. In this perspective, more studies are needed at the fund level to understand funds' behavior when facing significant outflows. 


\section{REFERENCES}

Abidi, N. and Miquel-Flores, I. (2018). Who benefits from the corporate QE? A regression discontinuity design approach. ECB, Working Paper $n^{\circ}$ 2145, April 2018.

Acharya, A., Anshuman, R., and Kumar, K. "Foreign Fund Flows and Stock Returns: Evidence from India." Working paper, New York University.

Anand, A., Jotikasthira, C., Venkataraman, K. "Do Buy-Side Institutions Supply Liquidity in Bond Markets? Evidence from Mutual Funds", 28th Annual Conference on Financial Economics and Accounting, SMU Cox School of Business Research Paper No. 18-5.

Bao, J., Pan, J., and Wang, J., 2011. "The illiquidity of corporate bonds", Journal of Finance, vol 66, issue 3,p. $911-946$

Baranova, Y., Becker, S., Grillet-Aubert, L., and T.S. Pinheiro. 2018. "Investment fund stress testing - a macroprudential perspective". ESRB OP 2018.

Bellando, R., and Tran-Dieu, L.T., 2011. " Fund flow/performance relationship: a case study of French mutuals funds". Revue Economique $n^{\circ} .2$

Ben-Raphael, A., S. Kande, and A.Wohl. 2011. "The Price Pressure of Aggregate Mutual Fund Flows." Journal of Financial and Quantitative Analysis 46 (2): 585-603.

Chernenko, S., and Sunderam, A. 2016. "Liquidity transformation in asset management: Evidence from the cash holdings of mutual funds", Fisher College of Business Working Paper, 2016.

Chevalier, J.A., and Ellison, G.D. 1997. "Risk-taking by mutual funds as a response to incentives", The Journal of Political Economy, 105(6), pp 1167-1200

Choi, J., Kronlund, M. 2018. Reaching for Yield in Corporate Bond Mutual Funds. The Review of Financial Studies, Volume 31, Issue 5, 1 May 2018, Pages 1930-1965

Choi, J., Shin, S.S., 2016. Is there flow-driven price impact in corporate bond markets? Mimeo.

Coudert, V., Couharde, C., and Mignon, V., 2011. Exchange rate volatility across financial crises", Journal of Banking \& Finance, Volume 35 (11), November, p. 3010-3018.

Coval, J., and E.Stafford. 2007. "Asset Fire Sales (and Purchases) in Equity Markets." Journal of Financial Economics 86 (2): 479-512.

De Santis, R, A. Geis, A. Juskaite and L. Vaz Cruz. 2018. "The impact of the corporate sector purchase programme on corporate bond markets and the financing of euro area non-financial corporations", European Central Bank Economic Bulletin, Issue 3 / 2018.

Driscoll, J.C., and A.C. Kraay, 1998. Consistent covariance matrix estimation with spatially dependent panel data, The Review of Economics and Statistics, 1998, vol. 80, issue 4, 549-560.

Edelen, Roger. 1999. "Investor Flows and the Assessed Performance of Open-end Mutual Funds." Journal of Financial Economics 53 (3): 439-66.

Edelen, R. and J. Warner. 2001. "Aggregate Price Effects of Institutional Trading: A Study of Mutual Fund Flow and Market Returns." Journal of Financial Economics 59: 195-220.

Feroli, M., Kashyap, A.K., Schoenholtz, K.L. , Shin, H.S. , 2014. In: Morgan Chase, JP (Ed.), Market tantrums and monetary policy. University of Chicago, New York University and Bank of International Settlements. Unpublished working paper.

Fourel, J. and V. Potier, 2015. Fonds d'investissement non monétaires français. Faits saillants pour l'année 2014 et le premier trimestre 2015. Bulletin de la Banque de France, $3^{\mathrm{e}}$ trimestre 2015.

Frazzini, A., Lamont, O.A., 2008. Dumb money: mutual fund flows and the cross-section of stock returns. Journal of Financial Economics 88, 299-322.

Goldstein, I., Jiang, H., Ng, D., 2017. "Investor flows and fragility in corporate bond funds", Journal of Financial Economics, vol. 126 (3), pages: 592-613.

Greenwood, R. and Thesmar, D.,(2011) Stock price fragility, Journal of Financial Economics, 2011. 
Han S., Zhou H. 2016. "Effects of liquidity on the non-default component of corporate yield spreads: evidence from intraday transactions data", Quarterly Journal of Finance, 6 (2016), pp. 129-178

Huang, J., Wei, K.D., Yan, H. , 2007. "Participation costs and the sensitivity of fund flows to past performance". The Journal of Finance 62, 1273-1311.

IMF 2015, Global Financial Stability Report , April, Chapter 3.

Ippolito (1992), Consumer Reaction to Measures of Poor Quality: Evidence from the Mutual Fund Industry, Journal of Law and Economic, 35(1) pp 45-70.

Jondeau \& Rockinger (2004) “The Bank Bias: Segmentation of French Fund families" Notes d'Etudes et de Recherches de la Banque de France n`107.

Longstaff, F., Mithal, and S., Neis, E. 2005. "Corporate Yield Spreads: Default Risk or Liquidity? New Evidence from the Credit Default Swap Market," Journal of Finance, vol. 60(5), pages 2213-2253, October.

Lynch, A.W., and Musto, D.K., 2003. "How investors interpret past fund returns". The Journal of Finance 58, 2033-2058.

Manconi, A., Massimo, M., Ayako, Y. 2012 "The role of institutional investors in propagating the crisis of 2007-2008" Journal of Financial Economics 104 (2012) 491-518.

Moulton, B. R. (1990). An illustration of a pitfall in estimating the effects of aggregate variables on micro units. Review of Economics and Statistics, 72(2), 334-338.Ponsard, M and Salvio, A. 2018. Investment Funds in the euro area : an heterogeneous dynamic since 2009. Bulletin de la Banque de Franec, 216/2. March-April.

Rey, H., 2016. "International Channels of Transmission of Monetary Policy and the Mundellian Trilemma”, IMF Economic Review, May 2016, Volume 64 (1), pp 6-35.

Standard \& Poor's (2018). 2017 Annual Global Corporate Default Study and Rating Transitions". https://www.spratings.com/documents/20184/774196/2017+Annual+Global+Corporate+Default+Study /a4cffa07-e7ca-4054-9e5d-b52a627d8639

Sirri, Erik R., and Peter Tufano. 1998. "Costly Search and Mutual Fund Flows." Journal of Finance 53 (5): 1589-622.

Warther, V. A. 1995. "Aggregate Mutual Fund Flows and Security Returns." Journal of Financial Economics 39 (2-3): 209-35.

Zeng, Yao (2016). A Dynamic Theory of Mutual Fund Runs and Liquidity Management." ESRB Working Paper Series, No 42 / April 2017 